doi:10.1016/j.watres.2005.11.018

Copyright (c) 2005 Elsevier Ltd All rights reserved.

\title{
Evaluation of data from the literature on the transport and survival of Escherichia coli and thermotolerant coliforms in aquifers under saturated conditions
}

\section{J.W.A. Foppen ${ }^{a, *}$ and J.F. Schijven ${ }^{b}$}

aUNESCO-IHE Institute for Water Education, Department of Water Engineering, P.O. Box 3015, 2601 DA Delft, The Netherlands

${ }^{\mathrm{b}}$ National Institute of Public Health and the Environment, Microbiological

Laboratory for Health Protection, P.O. Box 1, 3720 BA Bilthoven, The Netherlands

* Corresponding author. Tel.: +31 152151832.

\begin{abstract}
Escherichia coli and thermotolerant coliforms are of major importance as indicators of fecal contamination of water. Due to its negative surface charge and relatively low die-off or inactivation rate coefficient, $E$. coli is able to travel long distances underground and is therefore also a useful indicator of fecal contamination of groundwater. In this review, the major processes known to determine the underground transport of $E$. coli (attachment, straining and inactivation) are evaluated. The single collector contact efficiency (SCCE), $\eta_{0}$, one of two parameters commonly used to assess the importance of attachment, can be quantified for $E$. coli using classical colloid filtration theory. The sticking efficiency, $a$, the second parameter frequently used in determining attachment, varies widely (from 0.003 to almost 1 ) and mainly depends on charge differences between the surface of the collector and E. coli. Straining can be quantified from geometrical considerations; it is proposed to employ a so-called straining correction parameter, $a_{\mathrm{str}}$. Sticking efficiencies determined from field experiments were lower than those determined under laboratory conditions. We hypothesize that this is due to preferential flow mechanisms, E. coli population heterogeneity, and/or the presence of organic and inorganic compounds in wastewater possibly affecting bacterial attachment characteristics. Of equal importance is the inactivation or die-off of $E$. coli that is affected by factors like type of bacterial strain, temperature, predation, antagonism, light, soil type, $\mathrm{pH}$, toxic substances, and dissolved oxygen. Modeling transport of E. coli can be separated into three steps: (1) attachment rate coefficients and straining rate coefficients can be calculated from Darcy flow velocity fields or pore water flow velocity fields, calculated SCCE fields, realistic sticking efficiency values and straining correction parameters, (2) together with the inactivation rate coefficient, total rate coefficient fields can be generated, and (3) used as input for modeling the transport of $E$. coli in existing contaminant transport codes. Areas of future research are manifold and include the effects of typical wastewater characteristics, including high concentrations of organic compounds, on the transport of $E$. coli and thermotolerant coliforms, and the upscaling of experiments to represent typical field conditions, possibly including preferential flow mechanisms and the aspect of population heterogeneity of $E$. coli.
\end{abstract}




\section{Introduction}

In developing countries in Asia, South America and Africa for an estimated 1300 million urban dwellers the main source of drinking water is groundwater (Foster, 2000). This groundwater may be contaminated by infiltrated wastewater, because very often a sewer system is not present and households dispose of their solid and liquid waste on-site. For instance, in Africa around $80 \%$ of the population in the largest cities (in Asia: around 55\%) have on-site sanitation, such as septic tanks, pour-flush, VIP latrines or simple pits (World Health Organization, 2000-2003). In some cases, the distance from pit latrine to abstraction well is small ( $<500 \mathrm{~m}$; Foppen, 2002) and there is then a real risk of abstracting pathogens. If this groundwater is not disinfected, those who drink it are at increased risk of infection and disease. Studies in the USA have shown that up to half of all US drinking water wells tested had evidence of fecal contamination and that an estimated 750,000-5.9 million cases of illness and 1400-9400 deaths per year may result from contaminated groundwaters (Macler and Merkle, 2000). In addition to leakage from on-site sanitation or from sewerage, the sources of fecal contamination could be manure, wastewater or sewage sludge spread by farmers on fields, waste from animal feedlots, waste from healthcare facilities, and leakage from waste disposal sites and landfills.

\subsection{Indicator organisms}

To predict the presence of pathogens in water, a separate group of microorganisms is usually used, generally known as fecal indicator organisms. Many microorganisms have been suggested as microbial indicators of fecal pollution (like enterococci, coliphages and sulphite reducing clostridial spores; Medema et al., 2003), but two of the most important indicators used worldwide are Escherichia coli and thermotolerant coliform bacteria (for microbiological definitions of these indicators, see Section 2.1). Both are widely used, because their detection is relatively simple, fast, and reliable. E. coli is the preferred indicator of fecal contamination, as it is the only member of the thermotolerant coliform group that is invariably found in feces of warm-blooded animals and it outnumbers the other thermotolerant coliforms in both human and animal excreta (Medema et al., 2003). Thermotolerant coliforms are a less reliable index of fecal contamination than E. coli, although under most circumstances their concentrations are directly related to $E$. coli concentrations (Payment et al., 2003). Viruses may be considered as the most critical or limiting microorganism. Because of their small size, their mostly negative surface charge, and their high persistence in the environment, they may travel long distances in the subsurface. In addition, they can be highly infectious (Schijven, 2001). In the study by Karim et al. (2004a), water from 20 groundwater wells from 11 US states was monitored monthly for 1 year for the presence of culturable viruses, nucleic acid of enteric viruses (enterovirus, hepatitis $A$, norwalk virus, rotavirus, and adenovirus) by RT-PCR, bacteriophages, and indicator bacteria (total coliforms, $E$. coli, enterococci, and spores of Clostridium perfringens). Virus occurrence was common: 17 of the 20 wells tested positive by cell culture or RT-PCR for enteric viruses. If indicators were to be used to monitor the probability of the fecal contamination of groundwater resources, the authors recommended using coliforms and F-specific bacteriophages in combination, because all the viruspositive wells were detected using both these indicators. If a single indicator were to be used, they recommended coliforms, because these were found to occur most frequently ( $80 \%$ of the sites) and were present at $82 \%$ of the virus-positive sites. 


\subsection{Aim of this review}

Although E. coli and thermotolerant coliforms as representatives of the group of fecal indicator organisms have often been found in groundwater systems, to date there has been no comprehensive report evaluating and discussing their transport characteristics. Various authors have reviewed the transport and survival of pathogenic and/or non-pathogenic microorganisms originating from wastewater. Some of the reviews concentrate on the movement of bacteria and viruses in aquifers in a qualitative way, without attempting to predict their migration (e.g. Romero, 1970; Lewis et al., 1980; Hagedorn et al., 1981; Crane and Moore, 1984; Bitton and Harvey, 1992; Stevik et al., 2004). Others mainly focus on firstorder die-off rates, thereby neglecting the transport component including attachment and detachment processes (e.g. Reddy et al., 1981; Barcina et al., 1997). Murphy and Ginn (2000) mainly summarize the mathematical descriptions of the various physico-chemical and biological processes involved in the transport of bacteria and viruses, without indicating the relative importance of these processes and their occurrence in the natural environment. Merkli (1975) and Althaus et al. (1982) have presented a comprehensive bacteria transport model based on the colloid filtration theory (Herzig et al., 1970; Yao et al., 1971), including the effects of dispersion, diffusion, sedimentation, and filtration. The effects of retardation due to equilibrium adsorption were also included, as well as the physical, chemical, and biological factors determining the die-off of pathogens and indicator organisms. Their findings, however, were based on relatively few data, derived from batch experiments and equilibrium sorption.

The aim of this review is to analyze and summarize existing models, parameters, and their values used to describe and quantify the attachment and inactivation of $E$. coli and thermotolerant coliforms during transport in aquifers under saturated conditions, with the aim of elucidating the relative importance of the various factors influencing transport. In order to illustrate the effect of solution chemistry and ionic strength on the variability of surface charge, we have included a set of E. coli zeta potential data from our own experiments. In addition, this review attempts to present a framework to help predict fecal indicator organism concentrations in aquifers. We conclude by using some example cases to demonstrate the importance of key parameters.

\section{Morphology and surface characteristics of $E$. coli}

\subsection{Taxonomy}

E. coli is a gram-negative, facultatively anerobic, straight, rod-shaped bacterium of 2.0-6.0 $\mu \mathrm{m} \times 1.1-1.5 \mu \mathrm{m}$ occurring singly or in pairs (Bergey et al., 1984) and is a taxonomically well-defined member of the family Enterobacteriaceae. Thermotolerant coliforms are defined as the group of coliforms that are able to ferment lactose at $44-45^{\circ} \mathrm{C}$. They comprise the genus Escherichia and, to a lesser extent, species of Klebsiella, Enterobacter, and Citrobacter. (Bergey et al., 1984). Of these organisms, only $E$. coli is considered to be specifically of fecal origin (Medema et al., 2003). Thermotolerant coliforms are frequently reported as fecal coliforms. However, this term is not correct (Payment et al., 2003), because not all thermotolerant coliforms may be of fecal origin: thermotolerant coliforms other than E. coli may originate from organically enriched water such as industrial effluents or from decaying plant materials and soils.

Most members of the E. coli species are considered to be harmless organisms, while some strains are responsible for illness. Three general clinical syndromes can result from infection with pathotypes: enteric/diarrhoeal disease, urinary tract 
infections, and sepsis/meningitis (Kaper et al., 2004). Pathogenic strains have been categorized into six groups, based on serological and virulence characteristics (Kaper et al., 2004; AWWA, 1999). Perhaps the most well-known pathogenic $E$. coli is the serotype $\mathrm{O} 157: \mathrm{H} 7$ of the enterohemorrhagic $E$. coli (EHEC) group.

\subsection{The surface of $E$. coli}

Bacterial attachment to surfaces is influenced by cell surface charge, hydrophobicity, size, and the presence of particular surface structures such as flagella, fimbriae, and extracellular lipopolysaccharides (Gilbert et al., 1991). Because of their physical location on the outside of $E$. coli, lipopolysaccharides (LPSs) are believed to be a key factor in the attachment of microbes to mineral surfaces, the uptake of metal ions, and microbially induced precipitation/dissolution reactions. The LPS of E. coli (Amor et al., 2000) consists of (i) a hydrophobic lipid A component anchored in the outer membrane, (ii) a phosphorylated, nonrepetitive hetero-oligosaccharide known as the core oligosaccharide, and (iii) a polysaccharide that extends from the cell surface and forms the $\mathrm{O}$ antigen detected in serotyping. Smooth LPS molecules found in most clinical isolates of $E$. coli are composed of this three-part structure, whereas rough LPS lacks the $O$ antigen and can have a truncated core OS (Kastowksy et al., 1991; Walker et al., 2004). The extent and structural diversity of LPS molecules in $E$. coli range from the highly conserved lipid $A$ to the extreme variations reflected in more than 170 known O antigens (Hull, 1997). The core OS is conceptually divided into inner and outer core regions. The inner core is composed primarily of L-glycero-D-manno-heptose (heptose) and 3-deoxy-Dmanno-oct-2-ulosonic (or 2-keto-3-deoxyoctulasonic) acid (KDO) residues; this part of the core oligosaccharide is phosphorylated in $E$. coli. Most of the charge on the LPS is concentrated in these phosphate groups of the inner core, and to a lesser extent on carboxylic acid groups of KDO (Kastowksy et al., 1991). The molecular interactions of these bacterial surface functional groups control attachment to surfaces. In Section 9 of this paper (factors affecting the collision efficiency), more attention will be paid to the influence of LPS structure on the transport of $E$. coli in aquifers.

\subsection{E. coli in water}

Usually, when $E$. coli bacteria are introduced into water environments, they gradually die and this process is accompanied by changes in their characteristics. Daubner (1975) carried out survival experiments using E. coli strains freshly isolated from the excreta of healthy persons in sterile demineralized water, Danube water, and highly mineralized water. He monitored the morphological and physiological properties of $E$. coli during die-off. Five to twenty hours after $E$. coli had been transferred to the sterile water, shrinking of the cell and the reduction of cytoplasmatic content (distilled and Danube water) or damage to the integrity of the cell (mineralized medium) was observed. Kerr et al. (1999) also observed widespread damage to the majority of cells of $E$. coli $0157: \mathrm{H7}$, with large spaces between cell wall and cell membrane. In addition, Daubner (1975) observed changes in the biochemical activity of the cells, the most important ones being an immediate decrease in respiration and dehydrogenase activity of the cells when introduced into the water environments. Another important biochemical activity change was the utilization of citrate as a sole carbon source. During survival of $E$. coli STCC 416 under adverse conditions, Arana et al. (2004) observed the release of proteins, dissolved free amino acids, and dissolved monomeric carbohydrates into the surrounding medium and the transition from the culturable state to the viable but non-culturable (VBNC) state. In the VBNC state $E$. coli cells maintain 
their integrity and some metabolic activity, but they lose the ability to grow in culture media (Barcina et al., 1997). The obvious question is what effect these morphological and physiological changes will have on bacterial adhesion. For a number of strains (none of them E. coli), Kjelleberg and Hermansson (1984) studied the effects of starvation on bacterial surface characteristics; they also studied the changes in adhesion characteristics. They reported a considerable decrease in cell volume in the course of the starvation process (which lasted 22 hours in their study), which corroborates the findings of Daubner (1975) and Kerr et al. (1999) for $E$. coli. Furthermore, a number of strains exhibited increases in both hydrophobicity and irreversible binding to glass surfaces, initiated after different starvation times.

\subsection{Hydrophilic bacterial cell wall}

The role of bacterial cell wall hydrophobicity in attachment has also been recognized in a number of other studies (van Loosdrecht et al., 1987a and van Loosdrecht et al., 1987b; Gilbert et al., 1991; Noda and Kanemasa, 1986). Van Loosdrecht et al. (1987b) identified a positive relation between the bacterial hydrophobicity of 23 strains and their adhesion to negatively charged polystyrene disks, irrespective of their surface charge. They found that the contact angles of a $0.1 \mathrm{M} \mathrm{NaCl}$ suspension with E. coli NCTC 9002 and E. coli $\mathrm{K}-12$ were $16^{\circ}$ and $24^{\circ}$ respectively, which is relatively small in both cases. Because of the small contact angle the hydrophobicity was low, as was adhesion to the polystyrene disks. It was therefore concluded that $E$. coli is poorly adhesive. Noda and Kanemasa (1986) also found that E. coli was poorly hydrophobic; as a measure of hydrophobicity they determined the attachment of a nonionic surfactant to eight bacterial strains. They found that the E. coli K-12 adsorbed much less surfactant (37-69 $\mu \mathrm{g}$ surfactant/15 mg dry weight bacteria) compared to the other strains used in their experiments.

From these studies (Gilbert et al., 1991; van Loosdrecht et al., 1987a and van Loosdrecht et al., 1987b; Noda and Kanemasa, 1986), it can be concluded that $E$. coli is more of a hydrophilic than a hydrophobic organism. Gilbert et al. (1991) measured the hydrophobicity at regular intervals during the growth phase of $E$. coli ATCC 8739 and observed a significantly lower hydrophobicity during the midexponential growth phase than during the early growth and the stationary end phases. Gilbert et al. (1991) also measured the ability of $E$. coli to adhere to nitric-acid cleansed glass surfaces during the bacterial growth phase. A clear relationship was identified between decreased zeta potential (more surface negativity) and decreased attachment $\left(r^{2}=0.91\right)$. However, hydrophobicity did not correlate with adhesion $\left(r^{2}=-0.004\right)$. Based on these findings, Gilbert et al. (1991) refined the general hypotheses by van Loosdrecht et al. (1987a) and arrived at the important conclusion that for relatively hydrophilic organisms, such as $E$. coli, the hydrophobicity did not determine adhesion. Instead, the primary modulator of adhesion appeared to be the zeta potential. Scholl et al. (1990) and Scholl and Harvey (1992) also concluded that for relatively hydrophilic organisms, the major factor controlling the initial adhesion of bacteria is the surface charge of the minerals in the aquifer.

\subsection{The surface charge of $E$. coli}

Cell surface charge, e.g., as a result of charged functional groups on the LPS of $E$. coli, is not measured directly, but is usually determined via the so-called electrophoretic mobility, which is a measure of the zeta potential (defined as the potential drop across the mobile part of the double layer that is responsible for electrokinetic phenomena; Stumm and Morgan, 1996). To illustrate the variability 
of charge on the outer membrane of $E$. coli, we determined in our laboratory the zeta potential of $E$. coli ATCC 25922 in various solutions. To do so, we prepared bacterial suspensions consisting of various electrolyte concentrations and stored these for $24 \mathrm{~h}$ in the dark at room temperature $\left(20^{\circ} \mathrm{C}\right)$ prior to measuring electromobility with a zeta-meter similar to the one made by Neihof (1969). Movement of bacteria was visible on a video screen attached to a camera mounted on top of a light microscope (Olympus EHT) in phase contrast mode. Velocity measurements on each particle were made over $100 \mu \mathrm{m}$ in both directions by reversing the current (by applying a voltage potential varying between 20 and $90 \mathrm{~V}$ across the cell). Particle mobility values were obtained from measurements on at least 20 particles. Velocity measurements were used to calculate the zeta potential with the Smoluchowski-Helmholtz equation. The results (Fig. 1) indicated that in solutions of monovalent $\left(\mathrm{NaHCO}_{3}\right.$ and $\left.\mathrm{NaCl}\right)$ and divalent $\left(\mathrm{CaCl}_{2}\right.$ and $\left.\mathrm{MgSO}_{4}\right)$ electrolytes with ionic strength values ranging from $10^{-5}$ to $400 \mathrm{mM}$, within a $\mathrm{pH}$-range of 7.19-8.81, the zeta potential ranged from -20 to $-170 \mathrm{mV}$. In the divalent electrolytes, the zeta potential was considerably less negative than in the monovalent electrolytes, while $\mathrm{pH}$ variations did not seem to be very important. This can be explained in qualitative terms by the Schultze-Hardy rule, which states that the coagulation of a colloid is affected by that ion of an added electrolyte which has a charge opposite in sign to that of the colloidal particle, and the effect of such ion increases markedly with the number of charges it carries (Sawyer et al., 1994).

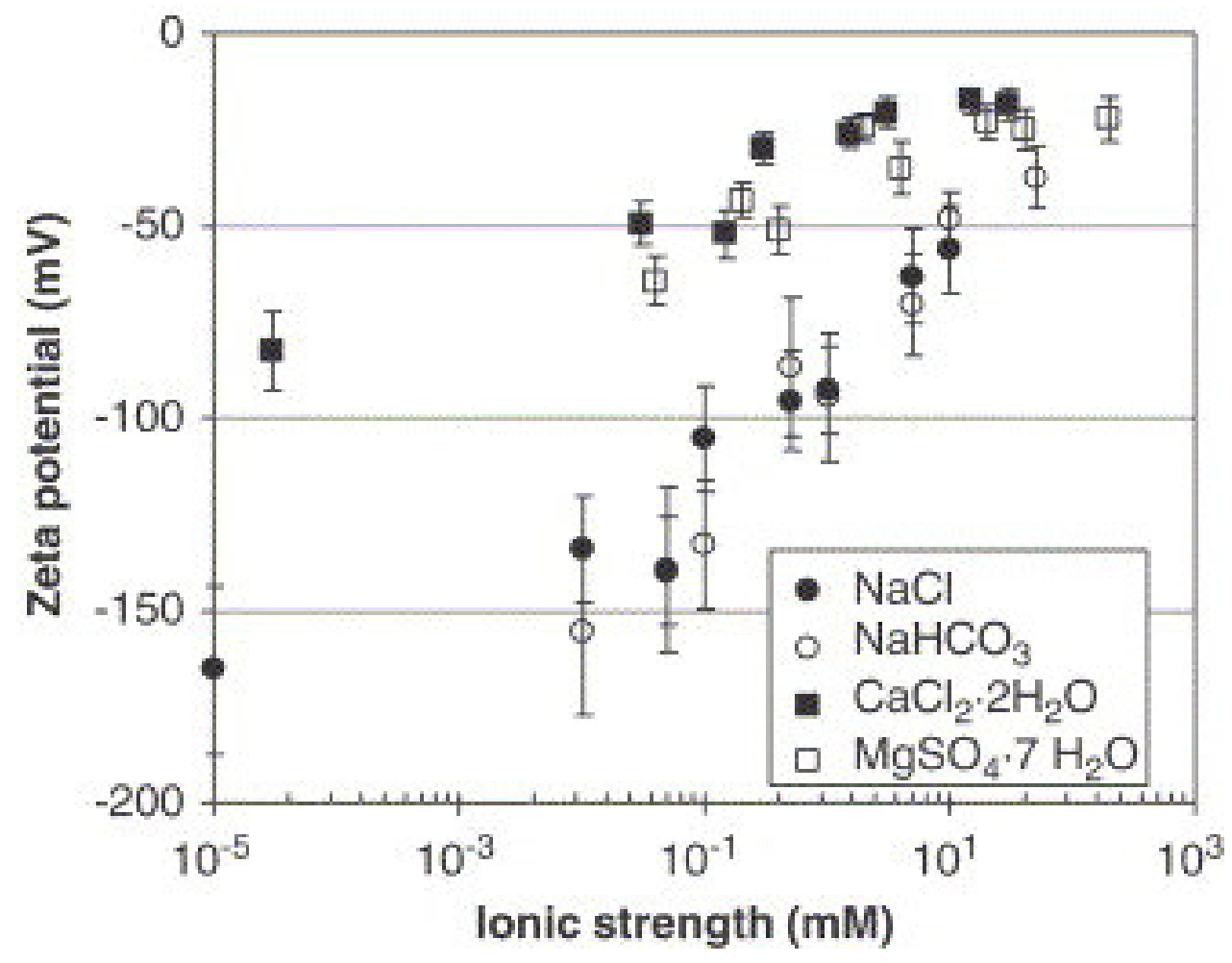

Fig. 1. Zeta potential as a function of ionic strength of various solutions for $E$. coli ATCC 25922 (our measurements). Error bars indicate one standard deviation.

Solution pH-values: $\mathrm{NaCl}$ and $\mathrm{CaCl}_{2} \cdot \mathrm{H}_{2} \mathrm{O}: \mathrm{pH}=7 ; \mathrm{NaHCO}_{3}$ : $\mathrm{pH}=8.35 ; \mathrm{MgSO}_{4} \cdot 7 \mathrm{H}_{2} \mathrm{O}$ : $\mathrm{pH}$ varies from 7.13 (at $0.01 \mathrm{mmol} \mathrm{L}^{-1}$ ) to 8.81 (at $50 \mathrm{mmol} \mathrm{L}^{-1}$ ). 


\subsection{Non-uniform surface charge distribution}

The zeta potential has two major shortcomings in characterizing the interaction between E. coli and collector surfaces (De Kerchove and Elimelech, 2005). Firstly, the zeta potential typically applies to hard spherical particles, whereas biological cells form a soft ion-permeable layer consisting of charged and non-charged LPS structures (Section 2.2) around the cell. The presence of such a layer controls the spatial distribution of the electric surface potential and the resulting interaction forces between a bacterial cell and solid surfaces. De Kerchove and Elimelech (2005) tested the applicability of an electrokinetic theory for soft particles to characterize the electrophoretic mobility and adhesion kinetics of various $E$. coli K12 mutants, and concluded that the theory failed to predict attachment efficiencies. The lack of success was attributed to chemical and physical heterogeneities of the polyelectrolyte layer at the cell surface. Secondly, the zeta potential is a macroscopic parameter that reflects the net or average electrokinetic properties of the cell and is not sensitive to small scale variations in the cell surface. Therefore, lumping this heterogeneous distribution of charge into one zeta potential value might result in erroneous predictions of $E$. coli-collector surface interactions. Walker et al. (2005) demonstrated that zeta potential values for $E$. coli D21 g harvested in the mid-exponential and in the stationary growth phase in solutions of various $\mathrm{KCl}$ concentrations were similar, while the bacterial deposition rate in columns packed with clean quartz sand (with a negative charge) at intermediate ionic strength values $(0.003-0.03 \mathrm{M} \mathrm{KCl})$ was at most 10 times higher for the stationary growth phase $E$. coli than for the mid-exponential E. coli. This was attributed to a combination of factors: (1) mid-exponential phase cells are covered with relatively simple proteins, while stationary-phase cells are covered with more complex LPS molecules, (2) apparently, upon approach toward the collector surface, the mid-exponential phase cells appear to be more uniformly (negatively) charged, while the stationary-phase cells will have a more uneven distribution of (negative) charge on the LPS molecules (phosphate and carboxyl groups), which resulted in less repulsion and more attachment of stationary-phase cells.

To summarize, E. coli bacteria have often been found in fecally contaminated groundwater, are easy to count, and are hydrophilic and strongly negatively charged. These properties make this bacterium a useful indicator of fecal contamination of groundwater, especially in developing countries lacking sufficient laboratory resources. In addition, some $E$. coli strains are enteropathogenic. Viruses may be considered more critical to groundwater quality than $E$. coli. Because of their smaller size, stability, and negative charge, they may be transported even further through the ground, and because of their infectiousness they represent a major threat to public health. However, the detection and enumeration of viruses, including bacteriophages requires more technical skills than needed for $E$. coli.

\section{General bacteria transport model}

The transport of mass in porous media may be generally described by the advection-dispersion-sorption (ADS) equation (De Marsily, 1986). Various expressions of the ADS equation have been used for the transport of colloids in general (Herzig et al., 1970; Yao et al., 1971; Corapcioglu and Haridas, 1984 and Corapcioglu and Haridas, 1985; Murphy and Ginn, 2000; Schijven, 2001) and, more particularly, for the transport of $E$. coli and thermotolerant coliforms (Pang et al., 2003; Powelson and Mills, 2001; Matthess and Pekdeger, 1981 and Matthess and Pekdeger, 1985; Matthess et al., 1985 and Matthess et al., 1988; Foppen et al., 2005). To appropriately describe the dynamic effects of colloid 
deposition and possible blocking effects, the colloid transport equation is expressed in terms of particle number concentration rather than mass concentration (Sun et al., 2001; Johnson et al., 1996) along with terms for attachment, detachment, straining, and inactivation or die-off (Bhattacharjee et al., 2002)

$$
\frac{\partial \mathrm{C}}{\partial \mathrm{t}}=\nabla \cdot(\mathrm{DVC})-\nabla \cdot(\mathrm{vC})-\frac{\mathrm{f}}{\mathrm{ra} \mathrm{a}_{\mathrm{p}}^{2}} \frac{\partial \mathrm{S}}{\partial \mathrm{t}}-\mathrm{k}_{\mathrm{i}} \mathrm{C},
$$

where $C$ is the number concentration of suspended bacteria in the aqueous phase $\left(\mathrm{m}^{-3}\right), D$ is the hydrodynamic dispersion coefficient $\left(\mathrm{m}^{2} \mathrm{~d}^{-1}\right), v$ is the pore water flow velocity $\left(\mathrm{m} \mathrm{d}^{-1}\right), f$ is the specific surface area of the porous medium $\left(\mathrm{m}^{-1}\right)$, $a_{\mathrm{p}}$ is the diameter of the bacteria $(\mathrm{m}), S$ is the dimensionless fractional surface coverage, which is defined as the total cross-section area of deposited bacteria per interstitial surface area of the porous medium solid matrix (Sun et al., 2001), $k_{\mathrm{i}}$ is the inactivation or die-off rate coefficient of bacteria in the fluid $\left(\mathrm{d}^{-1}\right)$, and $t$ is time (day). The dispersion coefficient is defined as (Corapcioglu and Haridas, 1984 and Corapcioglu and Haridas, 1985; Matthess and Pekdeger, 1981 and Matthess and Pekdeger, 1985)

$$
D=D^{\prime}+D_{B},
$$

where $D^{\prime}$ is the coefficient of mechanical dispersion due to the tortuosity of the pore channels and $D_{\mathrm{B}}$ is the coefficient of diffusion due to Brownian motion. $D^{\prime}$ depends on groundwater flow velocity and the dispersivity coefficient, which is a function of the inhomogeneity of the aquifer (e.g. De Marsily, 1986; Appelo and Postma, 1993). $D_{\mathrm{B}}$ can be estimated by the Stokes-Einstein equation (e.g. Corapcioglu and Haridas, 1984)

$$
\mathrm{D}_{\mathrm{E}}=\frac{\mathrm{kT}}{3 \pi \mathrm{wa}_{\mathrm{p}}},
$$

where $k$ is the Boltzmann constant $\left(1.2806 \times 10^{-23} \mathrm{JK}^{-1}\right), T$ is the temperature $(\mathrm{K})$ and $w$ is the dynamic water viscosity (Pa s; $1 \mathrm{~W}=9.85 \times 10^{15} \mathrm{~T}^{-17}$ when $273<T$ (temperature) $<303$ in $\mathrm{K}$; Matthess, 1982). For micron-sized particles (1$5 \mu \mathrm{m}$ ) at temperatures between 273 and $303 \mathrm{~K}, D_{\mathrm{B}}$ is in the range of $10^{-8} \mathrm{~m}^{2} \mathrm{~s}^{-1}$.

For bacteria retained by the solid matrix, several authors (Harvey and Garabedian, 1991; Lindqvist and Bengtsson, 1991; Lindqvist et al., 1994; Pang et al., 2003; Powelson and Mills, 2001; Matthess and Pekdeger, 1981 and Matthess and Pekdeger, 1985; Matthess et al., 1985 and Matthess et al., 1988) assume a fraction available for equilibrium sorption $\left(S_{1}\right)$ and a fraction available for kinetic sorption $\left(S_{2}\right)$, some (Tan et al., 1994; McCaulou et al., 1995; Hendry et al., 1997 and Hendry et al., 1999) assume only kinetic sorption $\left(S_{2}\right)$, while others (Bradford et al., 2003; Bradford and Bettahar, 2005; Foppen et al., 2005) assume kinetic sorption and a kinetic fraction available for straining $\left(S_{3}\right)$. Taking all these processes into account, the mass balance equation for retained bacteria can be expressed as 


$$
\begin{aligned}
& \frac{\partial \mathrm{S}}{\partial \mathrm{t}}=\frac{\partial \mathrm{S}_{1}}{\partial \mathrm{t}}+\frac{\partial \mathrm{S}_{2}}{\partial \mathrm{t}}+\frac{\partial \mathrm{S}_{3}}{\partial \mathrm{t}}-\mathrm{k}_{\mathrm{i} \mathrm{S}} \mathrm{S}, \\
& \mathrm{S}_{1}=\pi \mathrm{r}_{\mathrm{p}}^{2} \mathrm{~K}_{\mathrm{L}} \mathrm{C} \\
& \frac{\partial S_{2}}{\partial t}=\pi a_{p}^{2} k_{2} C B\left(S_{2}\right)-k_{\mathrm{i}} S_{2} \text {, } \\
& \frac{\partial S_{3}}{\partial t}=\pi a_{p}^{2} k_{s+1} C
\end{aligned}
$$

where $k_{\text {is }}$ is the inactivation or die-off rate coefficient of bacteria on the solid matrix $\left(\mathrm{d}^{-1}\right), K_{\mathrm{D}}$ is an empirical distribution coefficient $(\mathrm{m}), k_{\mathrm{a}}$ is the attachment rate coefficient $\left(\mathrm{m} \mathrm{d}^{-1}\right), k_{\mathrm{r}}$ is the detachment rate coefficient $\left(\mathrm{d}^{-1}\right), k_{\mathrm{str}}$ is the straining rate coefficient $\left(\mathrm{d}^{-1}\right)$, and $B\left(S_{2}\right)$ is the dimensionless dynamic blocking function. Blocking is the occlusion of collector surface resulting in a declining bacteria deposition rate as bacteria accumulate on that collector surface (Ryan and Elimelech, 1996). The dynamic blocking function can be expressed in terms of the random sequential adsorption model (Ko et al., 2000)

$$
\mathrm{B}\left(\mathrm{S}_{2}\right)=1-\mathrm{a}_{1} \mathrm{~S}_{2}+\mathrm{a}_{2} \mathrm{~S}_{2}^{2}+\mathrm{a}_{3} \mathrm{~S}_{2}+\cdots
$$

with appropriate values of the coefficients $a_{i}$. It should be noted that the more common Langmuirian adsorption model may also be employed to account for the blocking behavior, in which case Eq. (8) is truncated after the first-order term (Bhattacharjee et al., 2002; Ko et al., 2000). Inserting Eqs. (5), (6) and (7) in Eq. (4) yields the rate expression for the fractional surface coverage, $S$, of attached bacteria

$$
\frac{\partial S}{\partial t}=\pi \mathrm{a}^{2}\left\{\mathrm{~K}_{\mathrm{D}} \frac{\partial \mathrm{C}}{\partial \mathrm{t}}+\left(\mathrm{k}_{\mathrm{i}} \mathrm{B}\left(\mathrm{S}_{2}\right)+\mathrm{k}_{\mathrm{sit}}\right) \mathrm{C}\right\}-\mathrm{k}_{\mathrm{t}} \mathrm{S}_{2}-\mathrm{k}_{\mathrm{is}} \mathrm{S}
$$

Eqs. (1) and (9) are relatively simple general mass balance equations for bacteria in the fluid phase (Eq. (1)) and bacteria attached on the solid matrix in aquifers (Eq. (9)). More complex general colloid transport models are available. Sun et al. (2001) and Bhattacharjee et al. (2002) consider partial solid matrix mass balances for bacteria attached to favorable and unfavorable sites. Corapcioglu and Haridas, 1984 and Corapcioglu and Haridas, 1985 consider temporal and spatial changes in porosity due to bacterial attachment to aquifer grains. Others (e.g. Kim and Corapcioglu, 1996) consider the mass balances of an aqueous phase, a carrier phase, and a stationary solid matrix phase, with or without a contaminant present in one or all of the phases. Although it might be more appropriate from a theoretical point of view to use these more complex models, we used Eqs. (1) and (9), because, as will become clearer in Sections 4-13, the limited data available did not justify the use of more complex model descriptions. 


\subsection{Simplifying the rate expression for fractional surface coverage (Eq. (9)) for $E$. coli transport}

\subsubsection{Equilibrium sorption}

The so-called retardation factor due to equilibrium sorption, $R_{F}$, is defined as the ratio of the mean groundwater flow velocity, $v_{w}$, to the mean transport velocity of microorganisms, $v_{m}$ (Althaus et al., 1982; Harvey, 1997; Matthess et al., 1988; Sinton et al., 1997 and Sinton et al., 2000; Pang et al., 2003; see Eq. (9)). It can be approximated if the distribution coefficient, $K_{\mathrm{D}}$, of the bacteria is known:

$$
\mathrm{R}_{\mathrm{F}}=\frac{\mathrm{v}_{\mathrm{w}}}{\mathrm{v}_{\mathrm{m}}}=1+\pi \mathrm{a}_{\mathrm{p}}^{2} \mathrm{~K}_{\mathrm{D}} .
$$

In a number of studies (see Table 1), the retardation factor in the case of $E$. coli transport, either measured or fitted (from breakthrough curves), ranged between 0.1 and 2.81 (although mathematically $R_{F} \geqslant 1$ ); the average of all values mentioned in the table is 1.15 . Matthess et al. (1988) attributed retardation factors less than 1 to preferential transport of the microbes in the macropore systems of the aquifers. The explanation most commonly offered for this phenomenon is pore size exclusion (Harvey, 1997; Sinton et al., 1997 and Sinton et al., 2000; Sinton, 2001): larger particles such as bacteria cannot pass through smaller pores available to dissolved chemicals, but can only travel through the larger pores, where groundwater velocity is higher. However, in an injection experiment of a mixture of rhodamine WT dye, F-RNA phages, and thermotolerant coliforms into an aquifer, Sinton et al. (1997) observed that FRNA phages (with a diameter of $26 \mathrm{~nm}$ ) reached peak concentrations not only before the dye, but also before the thermotolerant coliform peak. Sinton et al. (1997) were unable to come up with a completely satisfactory explanation for this. One hypothesis was that the electrostatic repulsion forces might have been acting more strongly on phages than bacteria. Another more plausible explanation was that phages might have been adsorbed to particles of a size that are transported faster than bacteria (by pore size exclusion). On the basis of the data in Table 1 plus our own observations of $E$. coli in laboratory columns and in field tests, we believe that retarded breakthrough by equilibrium adsorption is of little significance. 
Table 1.

Retardation of Escherichia coli determined from field and laboratory experiments

\begin{tabular}{|c|c|c|c|c|}
\hline $\begin{array}{l}\text { Type of } \\
\text { experiment }\end{array}$ & $\begin{array}{c}\text { Retardation } \\
\text { factor }\end{array}$ & $\begin{array}{l}\text { Type of } \\
\text { microbe }\end{array}$ & Method & Reference \\
\hline \multirow[t]{2}{*}{$\begin{array}{l}\text { Column } \\
\text { experiment } \\
\text { (continuous } \\
\text { source) }\end{array}$} & $0.56-2.06$ & E. coli & $\begin{array}{l}\text { Fitted with } \\
\text { CXTFIT }^{\mathrm{a}}\end{array}$ & Pang et al., 2003 \\
\hline & $0.95-1.94$ & $F C$ & & \\
\hline \multirow{2}{*}{$\begin{array}{l}\text { Column } \\
\text { experiment (pulse } \\
\text { source) }\end{array}$} & $1.02-2.81$ & E. coli & & \\
\hline & $0.97-2.76$ & $F C$ & & \\
\hline $\begin{array}{l}\text { Column } \\
\text { experiment } \\
\text { (continuous } \\
\text { source) }\end{array}$ & $1.03-1.22$ & $\begin{array}{c}\text { E. coli } \\
\text { ATCC25922 }\end{array}$ & $\begin{array}{l}\text { Fitted with } \\
\text { CXTFIT }\end{array}$ & Powelson and Mills, 2001 \\
\hline \multirow[t]{2}{*}{$\begin{array}{l}\text { Field test (pulse } \\
\text { source, natural } \\
\text { gradient)) }\end{array}$} & 0.95 & $\begin{array}{c}\text { E. coli ATCC } \\
15224\end{array}$ & $\begin{array}{c}\text { Relative to } \\
\text { tracer velocity } \\
\text { (rhodamine WT) }\end{array}$ & Sinton et al., 1997 \\
\hline & 0.77 & $F C$ & & \\
\hline \multirow[t]{2}{*}{$\begin{array}{l}\text { Field test (pulse } \\
\text { source, natural } \\
\text { gradient)) }\end{array}$} & 0.50 & $\begin{array}{l}\text { E. coli ATCC } \\
15224\end{array}$ & $\begin{array}{c}\text { Relative to } \\
\text { tracer velocity } \\
\text { (rhodamine WT) }\end{array}$ & Sinton et al., 2000 \\
\hline & 0.74 & E. coli $\mathrm{K}-12$ & & \\
\hline $\begin{array}{l}\text { Field test (pulse } \\
\text { source) }\end{array}$ & $0.75-0.93$ & E. coli & $\begin{array}{l}\text { Relative to } \\
\text { tracer velocity } \\
\qquad\left({ }^{82} \mathrm{Br}\right)\end{array}$ & $\begin{array}{c}\text { Alexander and Seiler, 1983; } \\
\text { Havemeister and Riemer, 1985, } \\
\text { both in: Matthess et al., 1985 } \\
\text { and in Matthess et al., } 1988\end{array}$ \\
\hline $\begin{array}{l}\text { Field test in } \\
\text { fractured granite } \\
\text { (forced gradient) }\end{array}$ & 0.1 & E. coli & $\begin{array}{l}\text { Relative to } \\
\text { tracer velocity } \\
\text { (bromide) }\end{array}$ & Champ and Schroeter, 1988 \\
\hline $\begin{array}{l}\text { Column } \\
\text { experiment with } \\
\text { quartz }\end{array}$ & 1 & E. coli & $\begin{array}{l}\text { Relative to } \\
\text { tracer velocity }\end{array}$ & Merkli, 1975 \\
\hline $\begin{array}{l}\text { Column } \\
\text { experiment with } \\
\text { K-feldspar }\end{array}$ & 1 & E. coli & & \\
\hline $\begin{array}{l}\text { Column } \\
\text { experiment with } \\
\text { marble }\end{array}$ & 1 & E. coli & & \\
\hline $\begin{array}{l}\text { Column } \\
\text { experiment with } \\
\text { serpentine }\end{array}$ & 1 & E. coli & & \\
\hline
\end{tabular}

${ }^{\text {a }}$ CXTFIT curve-fitting program (Toride et al., 1999).

\subsection{Blocking}

Although blocking has been an important mechanism in some studies (Lindqvist et al., 1994; Johnson and Elimelech, 1995; Liu et al., 1995), it has not been used in the literature to explain the breakthrough of $E$. coli and thermotolerant coliforms, either in laboratory column experiments or in field tests. Even in longterm experiments of 3 months and longer (Butler et al., 1954; Bouwer et al., 1974b) with treated sewage effluent in rapid infiltration basins, there was no sign of blocking. The most plausible explanation for this is that grain surface coverage is apparently low due to relatively "low" bacteria concentrations and/or is kept low due to the die-off of attached bacteria (which free up the surface area again). 
The net result is that a decline in bacteria deposition rate has not yet been observed.

Because of the apparent insignificant equilibrium adsorption and the apparent lack of blocking, we assumed $K_{D}=0$ and $B\left(S_{2}\right)=1$. Therefore, Eq. (9) reduces to

$$
\frac{\partial S}{\partial}=\pi a_{p}^{2}\left(k_{1}+k_{s i t}\right) c-k_{t} S_{2}-k_{i} s_{,}
$$

which indicates that the transport of $E$. coli in aquifers is mainly controlled by five rate coefficients $\left(k_{\mathrm{a}}, k_{\mathrm{r}}, k_{\mathrm{str}}, k_{\text {is }}\right.$ in Eq. (11) and $k_{\mathrm{i}}$ in Eq. (1)).

\section{The attachment rate coefficient}

The attachment rate coefficient, $k_{a}$, can be determined by (Ryan and Elimelech, 1996; Johnson et al., 1996):

$$
\mathrm{k}_{\mathrm{i}}=\frac{W_{\mathrm{N}}}{4},
$$

where $\eta$ is the dimensionless single collector removal efficiency (SCRE) and $\varepsilon$ is the effective porosity. The SCRE is a parameter representing the ratio of the rate of particles striking a collector to the rate of particles approaching the collector. When the geochemical composition of the sediment is known, grain surface charge heterogeneity can be included in the formulation of the SCRE by (Johnson et al., 1996; Ryan et al., 1999; Elimelech et al., 2000)

$$
\eta=\eta_{0}\left[i \gamma_{[}+(1-\lambda) \gamma_{n}\right]=\eta_{0} \gamma_{\mathrm{w} \mathrm{i}_{2} \mid}
$$

where $\eta_{0}$ is the single collector contact efficiency (SCCE), determined from physical considerations (e.g. Tufenkji and Elimelech, 2004a; see Section 4.1), $a_{f}$ and $a_{\mathrm{u}}$ are the sticking efficiencies to favorable and unfavorable attachment sites respectively, and $\lambda$ is a dimensionless heterogeneity parameter describing the fraction of aquifer grains composed of minerals favorable for the attachment or of grains having patches favorable for attachment (Elimelech et al., 2000; Bhattacharjee et al., 2002). For $E$. coli, which at typical groundwater $\mathrm{pH}$ values $(6-8)$ is mostly negatively charged, favorable attachment sites are positively charged. Examples of the minerals commonly found in sediments that are positively charged at typical groundwater $\mathrm{pH}$ values are goethite, $(\mathrm{a}-\mathrm{FeOOH}$, $\mathrm{pH}_{\mathrm{PzC}}$ of pure goethite, not influenced by carbonate adsorption=9.0-9.1; Gaboriaud and Ehrhardt, 2003) and carbonates like calcite. Somasundaran and Agar (1967) determined the zero point of charge of freshly ground Iceland spar calcite, as measured by the streaming potential technique, to be within a $\mathrm{pH}$ range of $9.5-10.8$.

Eq. (13) is important, since it directly determines the attachment rate coefficient (Eq. (12)). Also, since in most of the cases in the literature the sediment is considered to be a homogeneous medium, Eq. (13) is useful for determining an overall collision efficiency, $a_{\text {total }}$, and an overall SCRE, $\eta_{\text {total }}$, for collector or sediment in which the favorable and unfavorable fractions are unknown (see Sections 11 and 14). 


\subsection{The single collector contact efficiency, $\eta_{0}$}

The SCCE is defined as (e.g. Tufenkji and Elimelech, 2004a):

$$
\eta_{0}=\eta_{\mathrm{D}}+\eta_{\mathrm{I}}+\eta_{\mathrm{G}}
$$

where $\eta_{\mathrm{D}}, \eta_{\mathrm{I}}$ and $\eta_{\mathrm{G}}$, represent theoretical values for the single-collector contact efficiency when the sole transport mechanisms are diffusion, interception, and sedimentation, respectively (Yao et al., 1971; Tufenkji and Elimelech, 2004a). There have been many studies to determine the SCCE, $\eta_{0}$. When comparing a number of filtration models with the experimental data from Yao et al. (1971), Logan et al. (1995) recommended the use of the model developed by Rajagopalan and Tien (1976) to calculate aquasol removals in packed beds. This model has been used very frequently (e.g. Tobiason and O'Melia, 1988; Martin et al., 1992; Rijnaarts et al., 1996; Ryan and Elimelech, 1996). However, the major shortcoming of the Rajagopalan and Tien model is the omission of the influence of hydrodynamic and Van der Waals interactions on the deposition of particles that are dominated by Brownian diffusion. Tufenkji and Elimelech (2004a) developed an equation that includes these hydrodynamic and Van der Waals interactions and defined the transport mechanisms diffusion, interception, and sedimentation as

$$
\begin{gathered}
\eta_{\mathrm{D}}=2.44 \mathrm{~A}_{\mathrm{S}}^{1 / 3} \mathrm{~N}_{\mathrm{R}}^{-0.05 \mathrm{~N}_{\mathrm{Re}}} \mathrm{N}_{\mathrm{R}}^{-0.715} \mathrm{~N}_{\mathrm{vd}}^{-0.052}, \\
\eta_{\mathrm{T}}=0.55 \mathrm{As}_{\mathrm{R}}^{1.675} \mathrm{~N}_{\mathrm{A}}^{0.125}, \\
\eta_{\mathrm{G}}=0.22 \mathrm{~N}_{\mathrm{R}}^{-0.24} \mathrm{~N}_{\mathrm{G}}^{1.11} \mathrm{~N}_{\mathrm{vd}}^{-0.053},
\end{gathered}
$$

where $A_{S}=\left(2\left(1-p^{5}\right) / 2-3 p+3 p^{5}-2 p^{6}\right)$ and $p=(1-\varepsilon)^{1 / 3}, N_{R}=\left(a_{\mathrm{p}} / a_{\mathrm{c}}\right)$ for interception, $a_{\mathrm{c}}$ is the median of the grain size number distribution $(\mathrm{m})$. The Peclet number $\mathrm{N}_{\mathrm{Pe}}=\left(\mathrm{VA}_{\mathrm{C}} / \mathrm{D}_{\mathrm{B}}\right)_{\text {for the sum of convection and diffusion. The van der Waals }}$ number characterizing the ratio of van der Waals interaction energy to the particle's thermal energy $N_{\mathrm{vdw}}=(H / k T)$, where $H$ is the Hamaker constant, assumed here to be constant at $6.5 \times 10^{-21} \mathrm{~J}$ (Walker et al., 2004). The attraction number representing the combined influence of the van der Waals attraction forces and fluid velocity on particle deposition rate due to interception $\mathrm{N}_{\mathrm{A}}=\left(\mathrm{H} / 12 \pi \mathrm{wa}_{\mathrm{p}}^{2} \eta_{\mathrm{i}}\right)$. The gravity number $\mathrm{N}_{\mathrm{g}}=\left(2 \mathrm{~g}_{\mathrm{p}}^{2}\left(p_{\mathrm{p}}-p_{\mathrm{f}}\right) / 9_{\mathrm{W}}\right)_{\text {for }}$ sedimentation, where $g$ is the gravitational accelaration constant $\left(9.81 \mathrm{~m} \mathrm{~s}^{-2}\right), \rho_{\mathrm{p}}$ is the particle density $\left(\mathrm{kg} \mathrm{m}^{-3}\right)$ and $\rho_{\mathrm{fl}}$ is the fluid density $\left(\mathrm{kg} \mathrm{m}^{-3}\right)$.

\section{The straining rate coefficient}

Straining is defined as the trapping of bacteria in pore throats that are too small to allow passage, and it results from pore geometry. Matthess and Pekdeger (1985) defined a so-called geometrical suffusion security $\delta$, or straining, as

$$
\delta=\frac{\mathrm{a}_{\mathrm{p}}}{0.12 \mathrm{~d}_{10}},
$$


where $d_{10}$ is the 10th percentile of the cumulative grain size distribution $(\mathrm{m})$. These authors hypothesized that straining occurs only if $\delta \geqslant 1.5$, i.e. when the bacteria are larger than $18 \%$ of $d_{10}$. However, Bradford et al., 2002 and Bradford et al., 2003 reported that straining was more pronounced than predictions based upon Eq. (16). A less empirical approach was followed by Herzig et al. (1970), who calculated the volume of spherical colloids that could be retained $(\sigma)$ based on purely geometrical considerations (e.g. Foppen et al., 2005; Corapcioglu and Haridas, 1984 and Corapcioglu and Haridas, 1985):

$$
\sigma=\frac{1-i_{i}}{2} \pi N\left(\frac{a_{i}}{a_{c}}\right)^{2} \sqrt{\left(1+\frac{a_{i}}{a_{c}}\right)^{2}-1},
$$

where $N$ is the coordination number or the number of contact points between grains. Foppen et al. (2005) determined the pore volume available for straining from modeling high concentration $E$. coli breakthrough curves, from geometrical considerations based on Herzig et al. (1970) and from a pore size density function, and concluded that pore volumes determined with those methods were in reasonable agreement. Neumann (1983) developed a geometrically derived contact efficiency due to straining, based on Hall (1957). Assuming the collector consists of spherical grains surrounded by six spherical collectors or grains of similar size, Neumann (1983) determined a straining contact efficiency $\left(\eta_{\mathrm{s}}\right)$ as

$$
\eta_{s}=\frac{12}{\pi \sqrt{2}}\left(\frac{a_{p}}{a_{c}}\right)^{3 / 2} 2_{2} .7\left(\frac{a_{p}}{a_{c}}\right)^{3 / 2}
$$

in which $\eta_{\mathrm{s}}$ can be interpreted as the probability of entering a pore in which straining can occur. The straining rate coefficient developed by Bradford et al. (2003) was proportional to $\left(a_{p} / a_{c}\right)^{1.42}$, which is surprisingly similar to the geometrically derived relation by Neumann. In order to arrive at a straining rate coefficient, both Neumann (1983) and Hall (1957) multiplied the straining contact efficiency by a correction parameter $\mathrm{K}$ to account for fluid velocity variations at pore level, grain geometry variations, and filter bed porosity. The need for a correction factor also emerged from Bradford's work (Bradford et al., 2003; Bradford and Bettahar, 2005). Bradford and his colleagues proposed a depthdependent dimensionless power law straining function with a value between 0 and 1. Comparing Eq. (18) with the straining rate coefficient determined by Foppen et al. (2005) from modeling breakthrough curves of $E$. coli in the case of straining also revealed the need for a correction factor. In the experimental work of Matthess et al., 1991a and Matthess et al., 1991b, Bedbur (1989), and Peters

(1989). Eq. (18) was used to account for straining, but Matthess used the sticking efficiency, $a$, to correct for the variations mentioned above. However, we believe that the latter is not a good concept, because colloid filtration theory describes the probability of colliding with the surface of a collector and the probability of remaining attached, whereas in straining it is the probability of being strained in a pore that is of concern. Therefore, in order to calculate the straining rate coefficient, we propose to combine Eqs. (18) and (12) into

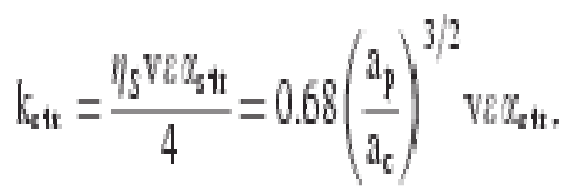


where $a_{\text {str }}$ is a dimensionless straining correction factor to account for fluid velocity variations at pore level, grain geometry variations, and filter bed porosity. It is tempting to interpret $a_{\text {str }}$ as the probability of a colloidal particle being retained due to purely geometrical considerations, once a pore in which straining can occur has been entered. If so, then the value of $a_{\text {str }}$ would be between 0 and 1. Experimental evidence (Bradford et al., 2003; Bradford and Bettahar, 2005; Matthess et al., 1991a and Matthess et al., 1991b) does indeed suggest this range of values, but this explanation needs to be confirmed by future research on straining.

\section{Relative importance of the bacteria transport mechanisms}

At Darcy groundwater velocities between 0.1 and $10 \mathrm{~m} \mathrm{~d}^{-1}$ and a grain size of $1 \mathrm{~mm}$, the diffusion and sedimentation components are the dominant bacterial transport mechanisms (see Fig. 2, upper graph). When Darcy flow velocity increases, the diffusion and sedimentation components decrease, and interception and straining remain unaltered. When the grain size decreases to $0.02 \mathrm{~mm}$ (the approximate boundary grain size value between silt and clay; Fig. 2, lower graph), then diffusion, interception, and straining are the dominant transport mechanisms. Sedimentation does not depend on grain size and remains unaltered.
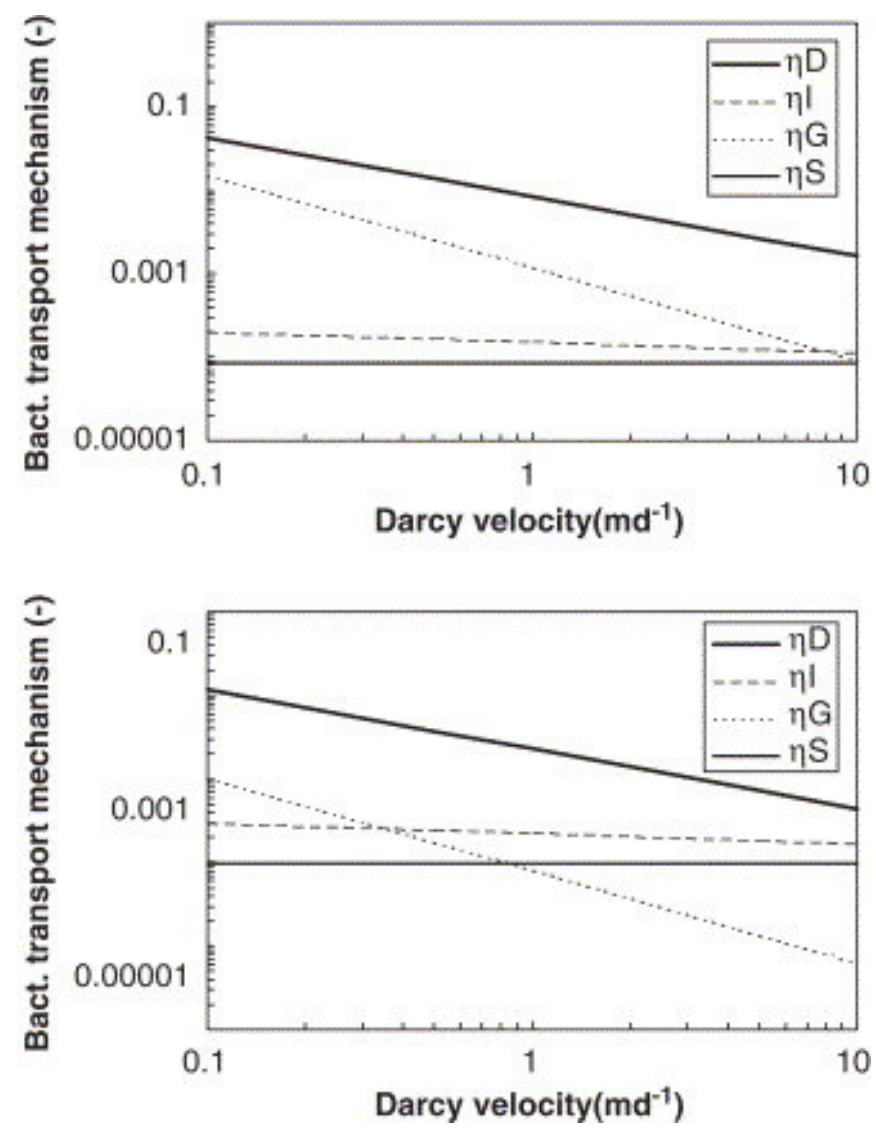

Fig 2. Magnitude of the single bacterial transport mechanisms as a function of Darcy flow velocity. Upper graph: $a_{c}=1 \mathrm{~mm}$; lower graph: $a_{c}=0.02 \mathrm{~mm}$. Other parameters (for both graphs): $T=283 \mathrm{~K}, a_{\mathrm{P}}=1 \mu \mathrm{m}, \varepsilon=0.35, H=6.5 \times 10^{-21} \mathrm{~J}$; $\rho_{\mathrm{p}}=1050 \mathrm{~kg} \mathrm{~m}^{-3}, \rho_{\mathrm{fl}}=1000 \mathrm{~kg} \mathrm{~m}^{-3}$, $=1.3 \times 10^{-3} \mathrm{~kg} \mathrm{~s} \mathrm{~m}^{-1}$. 


\section{The filter coefficient $(\boldsymbol{\beta})$}

The filter coefficient, $\beta\left(\mathrm{m}^{-1}\right)$, of an aquifer is the filter effect with respect to a certain flow length (Matthess et al., 1988; Rijnaarts et al, 1996). The initial concentration of a microbial suspension $C_{0}$ decreases along a flow length, $x$, to the observed concentration $C$ according to (Iwasaki, 1937; Matthess et al., 1988)

$$
C=C_{0} \mathrm{e}^{-\beta x}
$$

The filter coefficient is constant only at the beginning of the filter process during the clean bed collision phase, when deposited particles do not yet influence the transport of particles (Matthess et al., 1991a; Rijnaarts et al., 1996). In general, the filter coefficient, the SCRE, and the collision efficiency are related according to (Rijnaarts et al., 1996)

$$
\beta=\frac{3(1-\pi)}{2 a_{r}} \eta_{0} \alpha
$$

and when straining has to be included, the filter coefficient becomes

$$
\beta=\frac{3(1-d)}{2 a_{c}}\left(\eta_{0} z+\eta_{s} y_{s+1}\right)
$$

Combining Eqs. (12), (19) and (21a) yields

$$
k_{1}+k_{s t}=\frac{m k_{c}}{6(1-g)} v p .
$$

If the rate coefficients need to be expressed in $d^{-1}$, then the right-hand side of Eq. (22) has to be multiplied by the specific surface area $f=\left(6(1-\varepsilon) / \varepsilon a_{c}\right)$.

\section{Factors affecting the contact efficiencies}

\subsection{Effect of velocity}

According to Eqs. (15a) and (18), a number of parameters affect the SCCE and the straining contact efficiency: bacteria size, grain size, density of the fluid and the bacteria, temperature, velocity, and porosity. Matthess et al., 1991a and Matthess et al., 1991b carried out an extensive set of laboratory pulse source column experiments with pure quartz sand (unfavorable attachment) and $E$. coli ATCC11229 to test the effect of grain size, grain size uniformity, and velocity with constant bacteria size $(\sim 3 \mu \mathrm{m})$, constant density of fluid and bacteria (1000 and $\left.1050 \mathrm{~kg} \mathrm{~m}^{-3}\right)$, and constant temperature $(283 \mathrm{~K})$. The experiments were all carried out with artificial groundwater containing $526 \mathrm{mg} \mathrm{L}^{-1} \mathrm{CaCl}_{2} \cdot 2 \mathrm{H}_{2} \mathrm{O}$ and $184 \mathrm{mg} \mathrm{L}{ }^{-1} \mathrm{MgSO}_{4} \cdot 7 \mathrm{H}_{2} \mathrm{O}$ (ionic strength $=0.014 \mathrm{~mol}(\mathrm{~kg})^{-1}$ ) in order to exclude variations in bacteria attachment resulting from variations in solution chemistry. The variations in sediment chemistry between experiments were also negligible, since only quartz sand was used. The aim of the experiments was to evaluate the applicability of the filtration theory by comparing calculated and measured filter coefficients. The former was calculated with Eqs. (15a), (18) and (21a) and the latter was calculated with Eq. (20), with $\left(C / C_{0}\right)$ being determined from pulse 
source column breakthrough curves of known length $\mathrm{x}$. The results of more than 100 (triplicate!) column experiments are presented in Fig. 3. In order to arrive at the calculated filter coefficient, for all experiments we "calibrated" the same single collision efficiency, $a=0.43$ : this value gave the best fit between observed and calculated filter coefficients. Matthess et al. (1991b) used a sticking efficiency value of 0.4 . He arrived at this value by using other equations for the diffusion, interception, and sedimentation terms in Eq. (15) (based on Yao et al., 1971). Because the grain sizes that Matthess and co-workers used were mainly between 0.3 and $3 \mathrm{~mm}$ at a Darcy flow velocity range of $1-4 \mathrm{~m} \mathrm{~d}^{-1}$, the straining contact efficiency (Eq. (18)) was almost negligible. The fit was indeed reasonable, but not perfect. For instance, in the $0.4-1.0 \mathrm{~mm}$ grain size range, measured filter coefficients were scattered without a clear relationship between filter coefficient and velocity. The same was true for the $1.0-4.0 \mathrm{~mm}$ range. The reason for the scatter was that grain size uniformity fluctuated (see next section). Upon increasing grain size uniformity, the filter coefficient decreased somewhat. In general, the filter coefficient depended on groundwater flow velocity and on the grain size of the sediment. Also, there was reasonable agreement between the calculated and measured filter coefficients for various combinations of grain size and Darcy flow velocity.

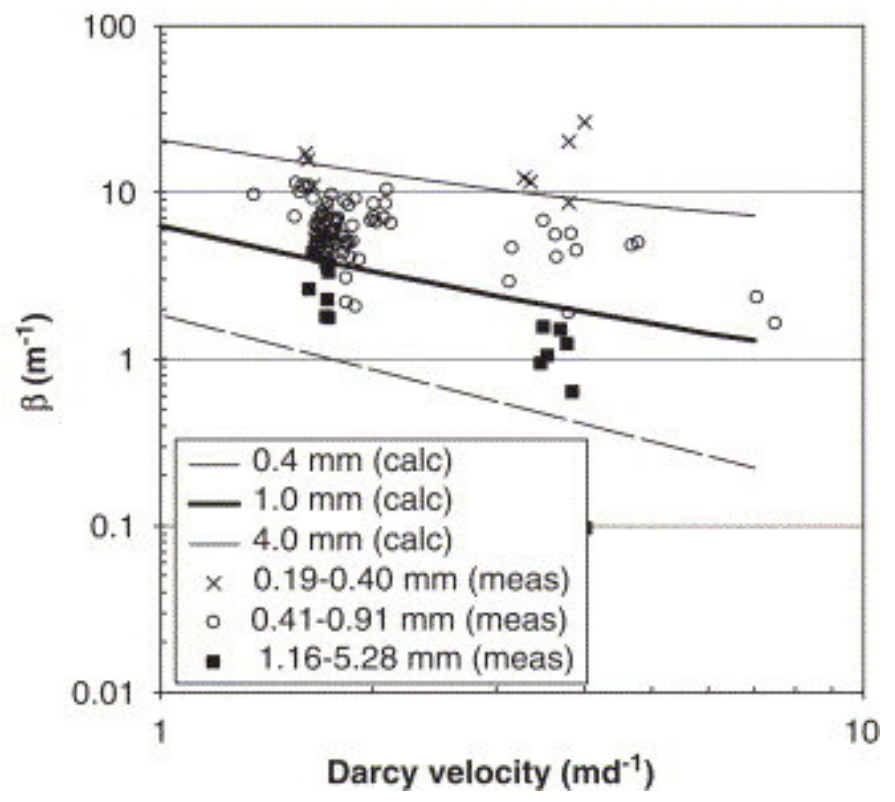

Fig. 3. Comparison of measured and calculated filter coefficients as a function of Darcy flow velocity $\left(\mathrm{m} \mathrm{d}^{-1}\right)$ and median of the grain size number distribution $(\mathrm{m})$. The calculated filter coefficient was determined with the SCCE according to the TE correction equation (Tufenkji and Elimelech, 2004a) and a collision efficiency, $a=0.43$.

\subsection{Effect of grain size}

Fig. 4 shows the calculated and measured filter coefficients plotted against $a_{c}$, the median of the grain size number distribution. Again, measured and calculated filter coefficients agreed reasonably well, but most of the measured filter coefficients for experiments with a grain size median around $0.45 \mathrm{~mm}$ were rather low, especially within the $1.0-3.0 \mathrm{~m} \mathrm{~d}^{-1}$ Darcy velocity range. This was because the grain size of this group of experiments was more uniform $(U>2)$ than in the other experiments $(U<2)$, bringing about a minor decrease in filter coefficient (see next section). Nevertheless, in this case too, the dependency of 
the filter coefficient on grain size and velocity was demonstrated, and there was reasonable agreement between the calculated and measured filter coefficients for various combinations of grain size and Darcy flow velocity.

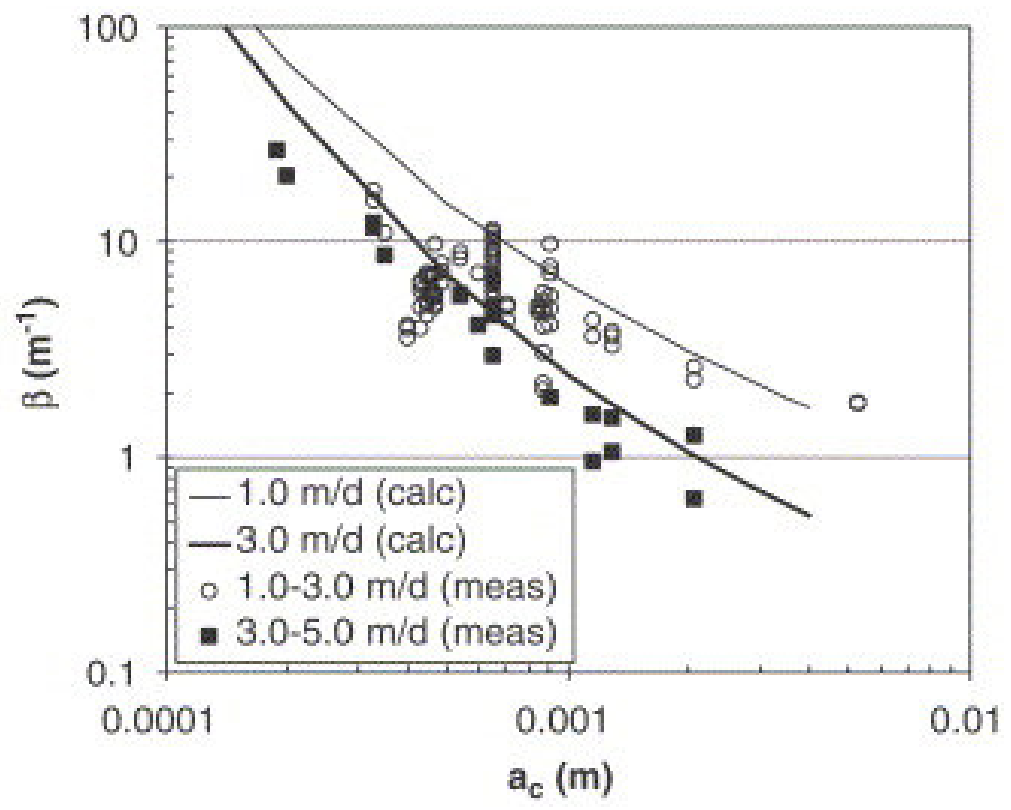

Fig. 4. Comparison of measured and calculated filter coefficients as a function of the median of the grain size number distribution $(\mathrm{m})$ and Darcy flow velocity $\left(\mathrm{m} \mathrm{d}^{-1}\right)$. The calculated filter coefficient was determined with the SCCE according to the TE correction equation (Tufenkji and Elimelech, 2004a) and a collision efficiency, $a=0.43$.

\subsection{Effect of grain size uniformity of sediment}

The uniformity of the sediment is defined as (Matthess et al., 1991a)

$$
\mathrm{U}=\frac{\mathrm{A}_{\mathrm{c}, 60}}{\mathrm{a}_{\mathrm{c}_{1} 10}},
$$

where the numbers 10 and 60 refer to the 10 th and 60th percentile values of the log-normal grain size number distribution curve. Matthess et al. (1991a) prepared a number of sediment mixtures in such a way that the median of the grain size number distribution curve (used in Eq. (21)) did not vary (it was taken at $0.45 \mathrm{~mm}$ ). The results demonstrated that the uniformity, $U$, did not significantly influence the filter coefficient of $E$. coli. While $U$ increased from 1.71 to 9.98 , the filter coefficient hardly changed.

We agree with the conclusions reached by Matthess et al., 1991a and Matthess et al., 1991b after their experiments, that measured filter coefficients and calculated filter coefficients determined with the SCCE (determined with the TE correction equation), neglecting straining and one sticking efficiency value of 0.43 , were in reasonable agreement. This demonstrates the usefulness of colloid filtration theory for predicting the transport of bacteria in porous media under saturated conditions. 


\section{Factors affecting the collision efficiency}

\subsection{Effect of zeta potential and solution chemistry}

The attachment of $E$. coli is governed not only by diffusion, sedimentation, interception, and straining, but also by the collision or sticking efficiency. As mentioned above, the empirical dimensionless sticking efficiency, $a$, describes the fraction of collisions with filter grains that result in attachment, and according to Gilbert et al. (1991), one of the main factors in the attachment process is the zeta potential. In addition to the strain of the bacterium, the main factor affecting the zeta potential-and therefore the collision efficiency-is the solution chemistry (see also Fig. 1). In a study by Sharma et al. (1985), the zeta potential of Grampositive (Bacillus subtillis) and Gram-negative (Pseudomonas fluorescens) bacteria in solutions consisting of various chemicals (heparin, polyacrylic acid, lignosulfonate, sodium pyrophosphate) varied between -20 and $-80 \mathrm{mV}$, depending on the chemical used. Sharma and co-workers found an excellent correlation between the surface charge of these bacteria and transportability (or lack of attachment) in columns filled with Ottawa sand (zeta potential between 30 and $-80 \mathrm{mV}$ ), which clearly suggested that electrostatic interactions between bacteria and sand grains were a dominant factor in their retention (Sharma et al., 1985). In a number of column experiments with E. coli ATCC 25922 and sand carried out by Powelson and Mills (2001), bacterial breakthrough was strongly dependent on the suspending solution used (see Fig. 5; the geochemical composition of the sand was not mentioned, but the breakthrough curves suggest that quartz sand was used=unfavorable conditions). In an attempt to explain these variations, in our experiments we determined the zeta potential of the bacteria in these solutions. To do so, solutions with E. coli ATCC 25922 similar to the ones made by Powelson and Mills (2001) were prepared and the zeta potential was determined in the same way as described in Section 2. Like Sharma et al. (1985), we also found an excellent correlation between surface charge (ranging from -17 to $-46 \mathrm{mV}$; see Fig. 5) and bacterial breakthrough. More generally, in a number of column experiments with quartz sand $(92.35 \%)$ with some carbonates $(2.4 \%)$ and iron $\left(\mathrm{Fe}_{2} \mathrm{O}_{3}+\mathrm{Al}_{2} \mathrm{O}_{3}\right.$ was $\left.0.77 \%\right)$, Goldshmid et al. (1973) found good agreement between the filter coefficient, the ionic strength of the electrolyte of the suspending solution, and the charge of the electrolyte used-which is in qualitative accordance with the Schulze-Hardy rule (see also Section 2). Note that on the negatively charged quartz sand in Goldshmid's experiments there were patches with a positive charge. At least the carbonates and possibly some of the iron were present as positively charged iron oxyhydroxide. We determined collision efficiencies from the filter coefficients and relative breakthrough concentrations determined by Goldshmid et al. (1973) and Powelson and Mills (2001) by using Eq. (20) and (21a); they are plotted in Fig. 6. Though the $a$ values were $a_{\text {total }}$-values in the case of Goldshmid et al. (1973) and unfavorable $a_{\mathrm{u}}$-values in the case of Powelson and Mills (2001), they can be compared, if it is assumed that the sediment fraction available for favorable attachment was limited. In all cases the $a_{s t r}$-value was negligible given the grain sizes used (ranging between $0.12-0.71 \mathrm{~mm}$ ). Fig. 6 clearly demonstrates the Schulze-Hardy effect: similar collision efficiencies are found for monovalent ( $\mathrm{Na}$, $\mathrm{K})$, divalent $(\mathrm{Mg}, \mathrm{Ca})$, and trivalent ( $\mathrm{Fe}(\mathrm{III})$ ) electrolytes for concentration ratios of about $1: 0.2: 0.0002$. The same effect is also achieved by changing the $\mathrm{pH}$. An increase in filtration efficiency was measured when the $\mathrm{pH}$ was lowered (from 9.3 to 3.9; Goldshmid et al., 1973). Interestingly, an increase in conductivity caused an increase in filtration efficiency at $\mathrm{pH}$ 9.3, and a decrease of efficiency at low $\mathrm{pH}$. At high $\mathrm{pH}$, the concentration of hydronium ions was so low that addition of sodium cations decreased the zeta potential slightly and increased the filtration efficiency. At low $\mathrm{pH}$ the effect was different and is attributable to the $\mathrm{pH}$ at the 
bacterial surface, $\mathrm{pH}_{\mathrm{s}}$, which differs from that in the bulk solution $\mathrm{pH}_{\mathrm{b}}$, particularly at low ionic strengths according to (Hartley and Roe, 1940, in: James, 1957)

$$
p \mathrm{H}_{\mathrm{a}}=\mathrm{p} \mathrm{H}_{\mathrm{b}}+0.21 / \mathrm{LM} \text {, }
$$

where $E M$ is the electrophoretic mobility $\left(\left(\mu \mathrm{m} \mathrm{s}^{-1}\right) /\left(\mathrm{V} \mathrm{cm}^{-1}\right)\right)$. Since the $E M$ of $E$. coli in low ionic strength solutions is around 2, the difference between both $\mathrm{pH}$ values is in the order of $0.4 \mathrm{pH}$ unit. As the salt concentration increases, the $\mathrm{pH}$ of the surface decreases towards that of the medium and the filtration efficiency increases. A similar phenomenon was observed by Scholl and Harvey (1992) in determining sorption of indigenous bacteria using contaminated and uncontaminated aquifer material from Cape Cod, MA.

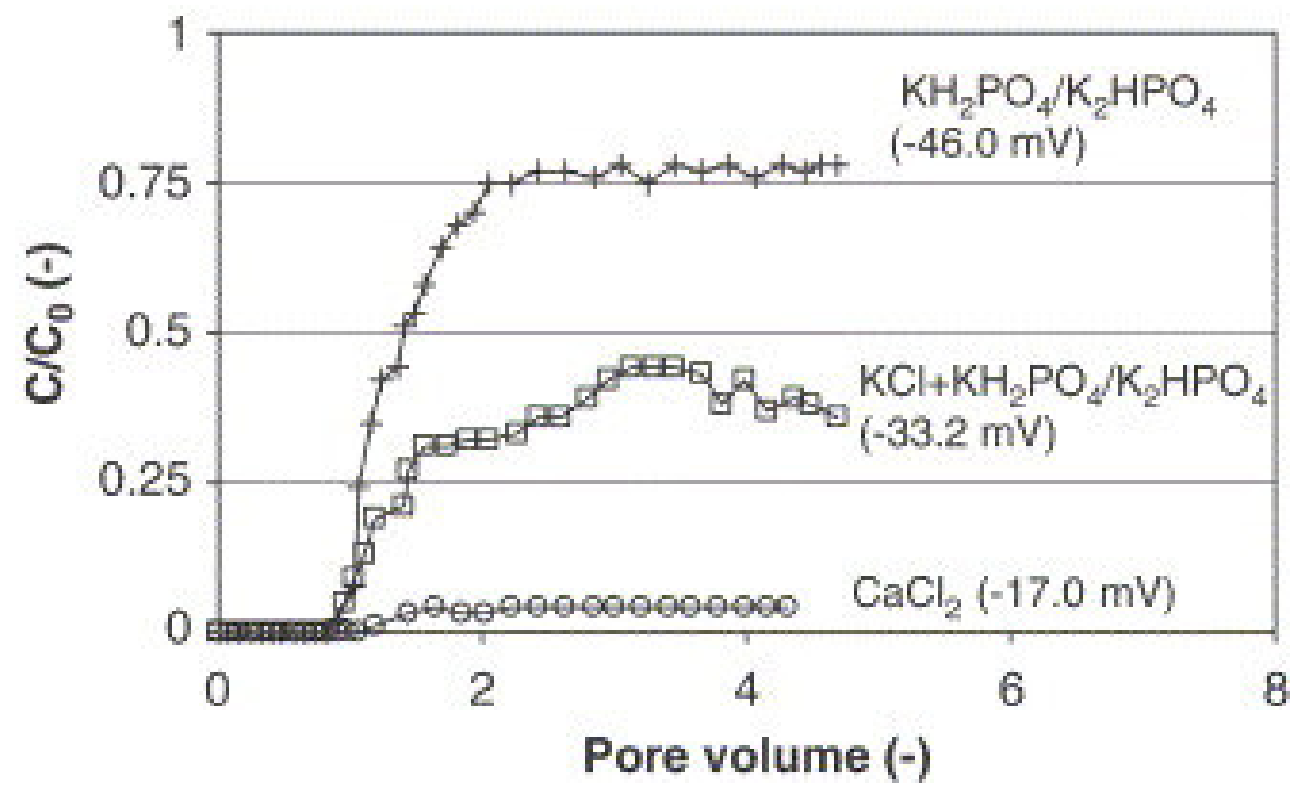

Fig. 5. Zeta potential values determined with the Helmholtz-Smoluchowksi equation and breakthrough curves of $E$. coli ATCC 25922 suspended in various solutions $\left(\mathrm{CaCl}_{2} ; \mathrm{KCl}\right.$ and dilute phosphate buffered saline; phosphate buffered saline; $C / C_{0}$ data are from Powelson and Mills, 2001). 


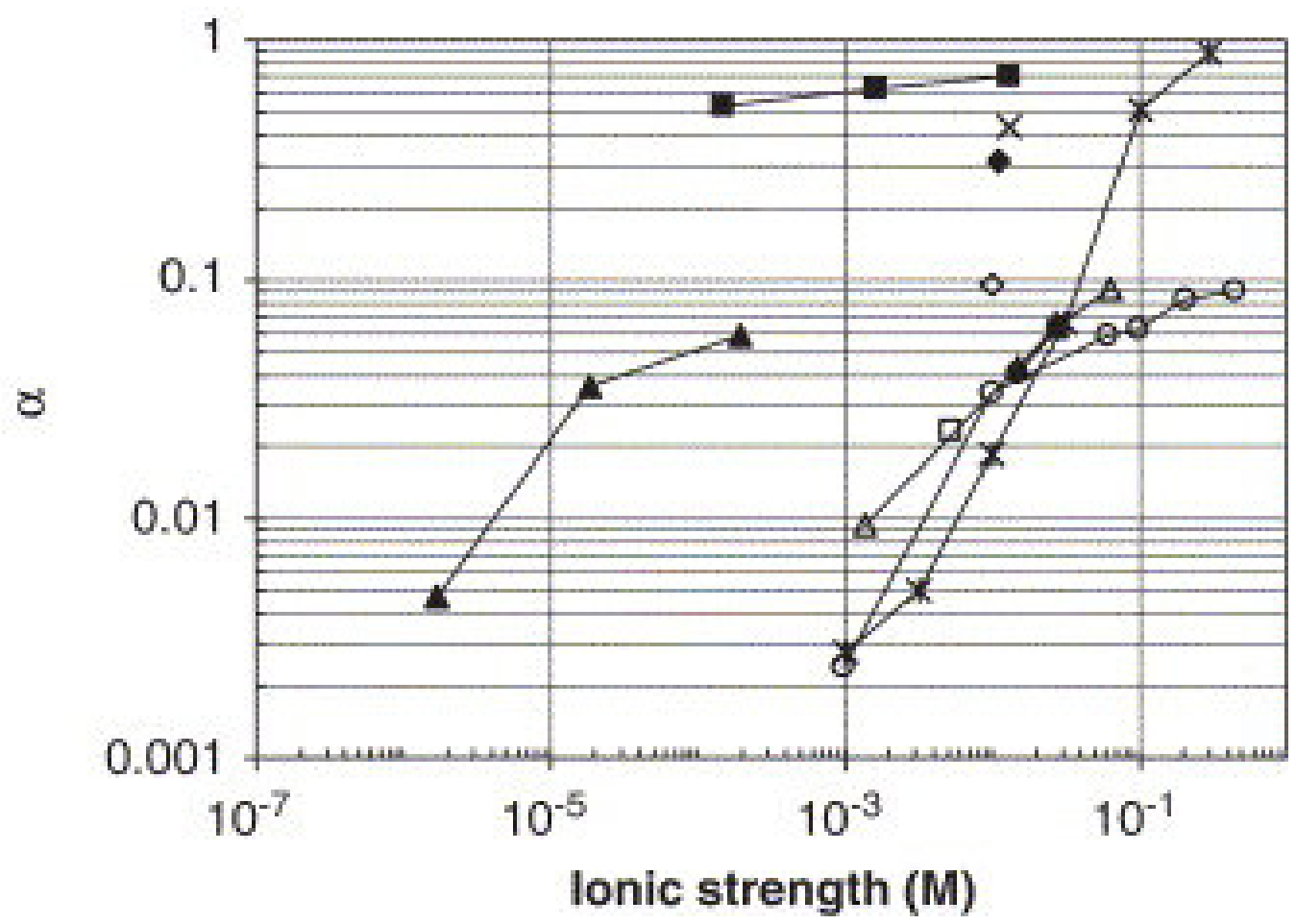

Fig. 6. Collision efficiency of $E$. coli as a function of the ionic strength of the solution and the valence of the electrolytes in solution. ( - Fe(III) (Goldshmid et al., 1973); $\triangle \mathrm{Ca}$ (Goldshmid et al., 1973); $\bullet \mathrm{Ca}\left(\right.$ from $\mathrm{CaCl}_{2}$; Powelson and Mills, 2001); - $-\mathrm{Ca}+\mathrm{Mg}$ (various ion strength values; explained intext); $\mathrm{XCa}+\mathrm{Mg}$ (Matthess et al., 1991b); - - Mg (Goldshmid et al., 1973); - - Na (Goldshmid et al., 1973); $\diamond \mathrm{K}$ (from KCl and $\mathrm{KH}_{2} \mathrm{PO}_{4} / \mathrm{K}_{2} \mathrm{HPO}_{4}$; Powelson and Mills, 2001); $\square \mathrm{K}$ (from $\mathrm{KH}_{2} \mathrm{PO}_{4} / \mathrm{K}_{2} \mathrm{HPO}_{4}$; Powelson and Mills, 2001); *-K (from KCl; Redman et al., 2004).

\subsection{Effect of ionic strength}

It is also clear from Fig. 6 that the collision efficiency increases with increasing ionic strength. This is the effect of ionic strength, which is usually explained by double-layer compression or a reduction in electrostatic force, which might cause the attractive van der Waals' force to predominate, resulting in more attachment. This is the basis of the so-called DLVO theory (after Darjaguin, Landau, Verwey and Overbeek; e.g. Schijven, 2001; Ryan and Elimelech, 1996; Sawyer et al., 1994). For $\mathrm{E}$. coli and for the type of water (a mixture of $\mathrm{Ca}, \mathrm{Mg}, \mathrm{Cl}$, and $\mathrm{SO}_{4}$ ions) used in the experiments with unfavorable quartz sand, Matthess et al., 1991a and Matthess et al., 1991b found a relationship between filter coefficient and ionic strength, $I$ :

$$
\beta=16.03+1.68 \log I .
$$

From this and by using Eq. (21), we calculated the relationship between unfavorable collision efficiency, $a_{u}$, and solution molarity $(M)$ :

$$
u_{1}=6.00 \log \left(17 \mathrm{M}-5.4 \times 0^{-5}\right)+0.86
$$


This relationship is plotted in Fig. 6 ("Ca+Mg various ionic strength values"). Note that at an ionic strength of 0.01 , the $a_{\mathrm{u}}$ deviates from the value 0.43 (see Fig. 6:

"Ca+Mg"), which was used to determine the calculated filter coefficient (solid and dashed lines in Fig. 3 and Fig. 4). We attribute this to Eqs. (25) and (26) being based on a limited dataset, whereas the $a$-value of 0.43 was based on more than 100 column experiments. Matthess et al. (1991b) concluded that when the ionic strength was greater than 0.01 , the unfavorable collision efficiency hardly varied with ionic strength. However, the data presented in Fig. 6 suggest otherwise: for solution ionic strength values between $10^{-3}$ and $1 \mathrm{M}$, the total collision efficiency $\left(a_{\text {total }}\right)$ for the bivalent ions $\mathrm{Ca}$ and $\mathrm{Mg}$ and the monovalent ion $\mathrm{Na}$ at least, showed a considerable increase.

\subsection{Effect of lipopolysaccharide composition in the outer membrane}

Walker et al. (2004) demonstrated that the composition of LPS in the outer membrane of $E$. coli can have a significant effect on collision efficiency (Fig. 7). Type D21g had a core oligosaccharide containing negatively charged phosphate groups, which resulted in little attachment (low sticking efficiency) in column experiments with negatively charged quartz sand. In contrast, LPS of strain JM109g consisted of an uncharged O-antigen, which appeared to be able to shield the phosphate charge, resulting in a marked increase of the sticking efficiency (more attachment).

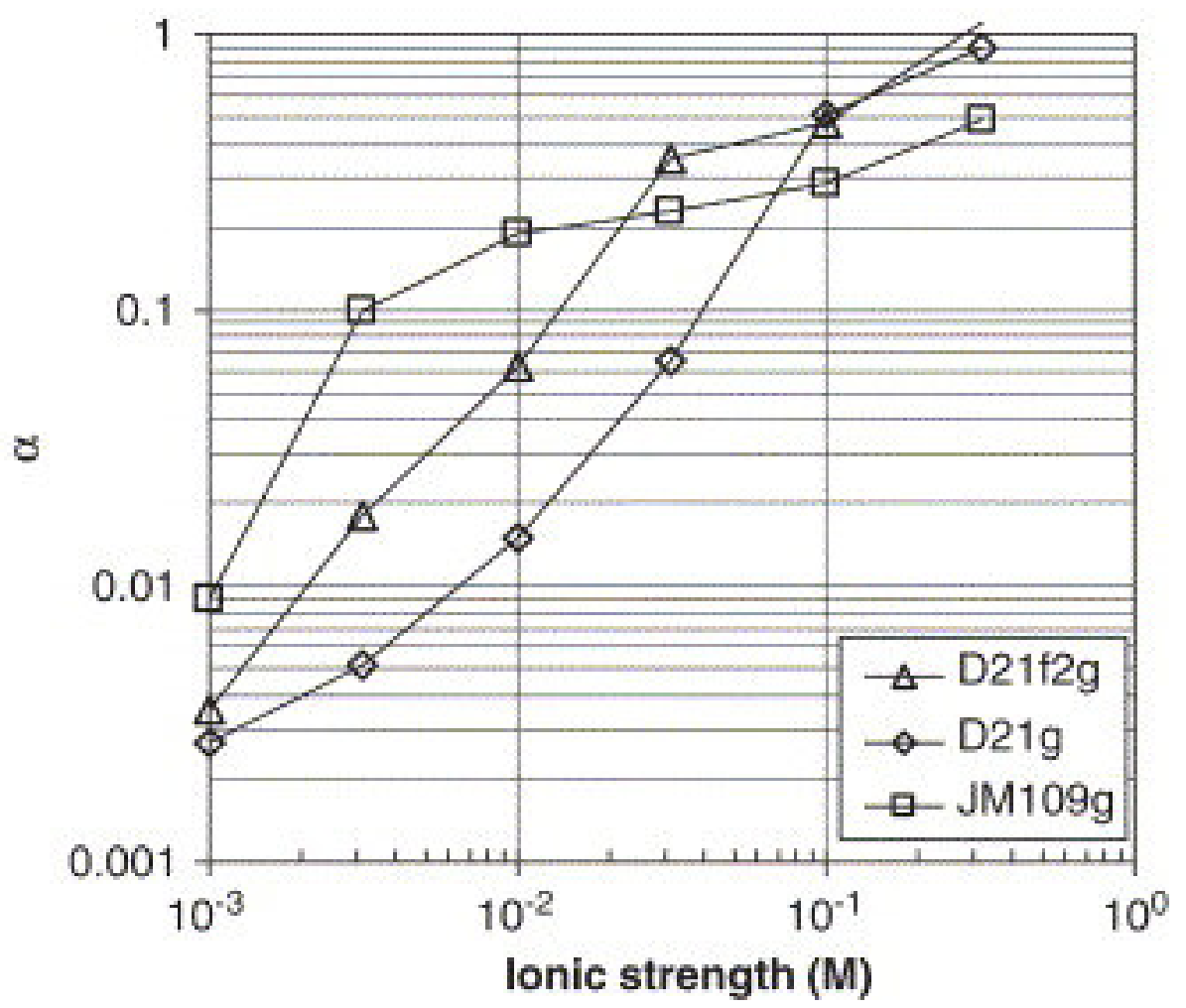

Fig. 7. Collision efficiency of three mutants of $E$. coli $\mathrm{K} 12$ with distinct portions of the LPS molecule (Walker et al., 2004) in column experiments containing quartz sediment. LPS of D21f2 $\mathrm{g}$ consists of lipid A and KDO; LPS of D21 g has lipid A, KDO and core oligosaccharide containing charged phosphate groups; LPS of JM109 g consists of lipid A, KDO, core oligosaccharide and O-antigen. JM109 g mutant "shields" the charge of the phosphate groups, resulting in a higher sticking efficiency and more attachment. 


\subsection{Effect of geochemical heterogeneity}

Johnson and Elimelech (1995) and Johnson et al. (1996) studied the effect of geochemical heterogeneity on the attachment of negatively charged artificial colloids during transport. They introduced the heterogeneity parameter, $\lambda$, in order to account for enhanced attachment due to the addition of positively charged iron-coated sand. Based on their results, the bacterial transport model in charged heterogeneous porous media (Eq. (13)) was developed. Foppen and Schijven (2005) determined the sticking efficiency of E. coli ATCC 25922 in a series of column experiments with sediments consisting of $0.18-0.50 \mathrm{~mm}$ quartz sand, goethite-coated grains, calcite grains or grains of activated carbon (AC), in varying fractions $(\lambda=0,0.05,0.1,0.2,0.4,0.7,1.0)$ and all of similar diameter to the quartz sand. The weighted sum of favorable and unfavorable sticking efficiencies $\left(a_{\text {total }}\right)$ showed that upon increasing the fraction of favorable mineral grains $(\lambda)$ there was an initial rapid increase, which then slowed down (Fig. 8). This was most pronounced in the AC experiments, followed by the calcite experiments, and then the goethite experiments. Foppen and Schijven (2005) attributed this non-linear relation to the surface charge and hydrophobic heterogeneity of the $E$. coli population. In a number of batch experiments, Scholl et al. (1990) investigated the rate and extent of attachment of Lula-D, an Arthrobacter sp., to chips of quartz, muscovite, limestone, and iron-coated quartz and muscovite, and found that the degree of attachment correlated with the sign of the surface charge of the minerals. In column experiments, maximum bacterial breakthrough in the case of iron-coated quartz was 2 log units lower than in the case of clean quartz. Also, a distinct "tailing" (or detachment) was observed.

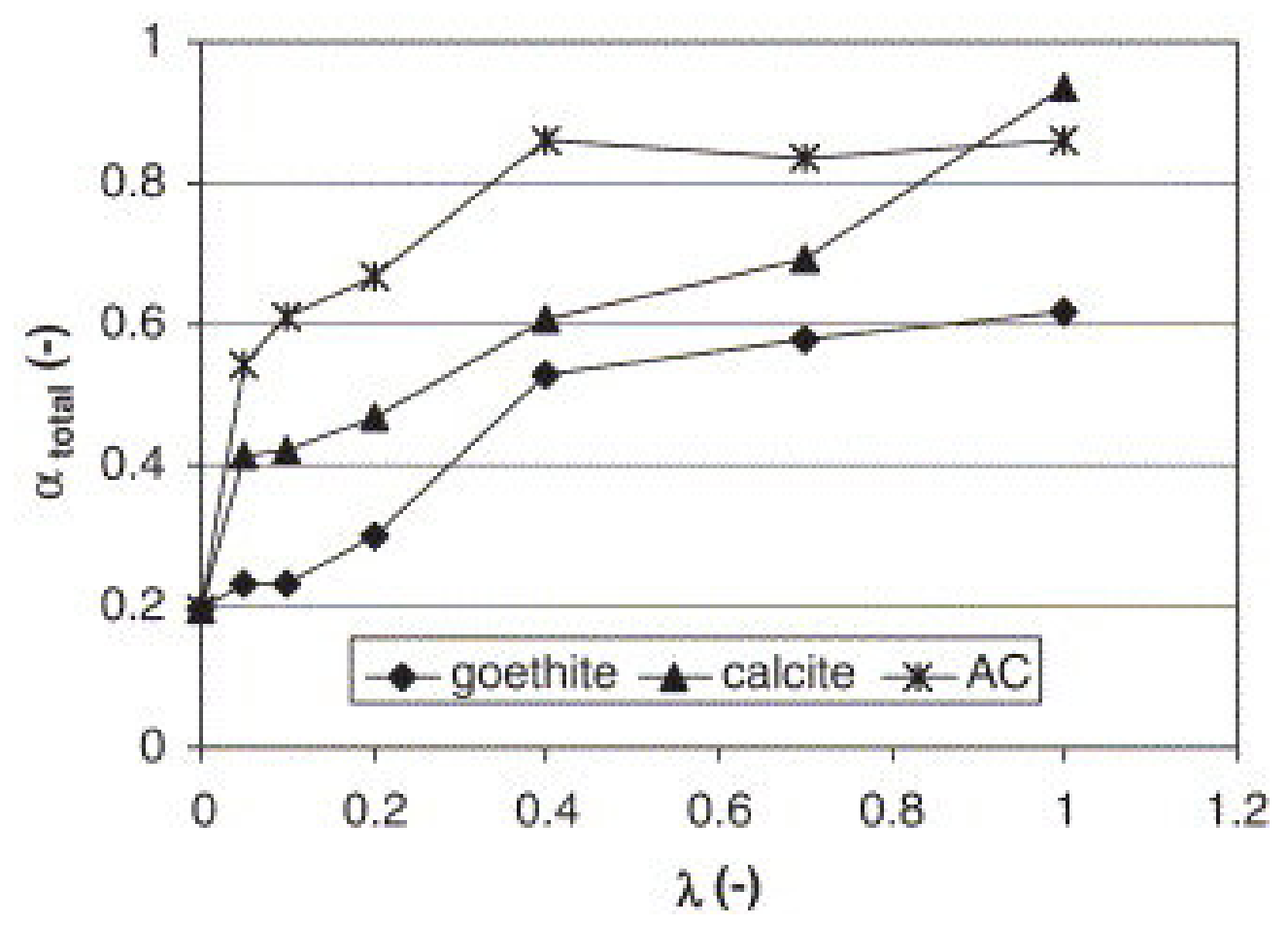

Fig. 8. Relation between calculated total sticking efficiency $\left(a_{\text {total }}\right)$ and geochemical heterogeneity parameter $(\lambda)$ for experiments carried out with quartz sand and goethite coated sand, quartz sand and calcite grains, and quartz sand and granular activated carbon (from: Foppen and Schijven, 2005). Fractions of goethite, calcite, and granular activated carbon varied from $5 \%$ to $100 \%$. 
In a series of batch and column experiments with indigenous bacteria using contaminated and uncontaminated aquifer material, Scholl and Harvey (1992) found that bacterial sorption was affected both by groundwater $\mathrm{pH}$ and by the presence of iron oxyhydroxide coatings around grains. The rate of attachment of $E$. coli to serpentine sand (with a high content of $\mathrm{Mg}$ minerals) increased concomitantly with the amount of sand added to the batch (Merkli, 1975). Also, the amount of adsorbed $E$. coli at equilibrium (after 2-8 h) increased upon increased amount of serpentine sand. The amount of $E$. coli attached to plagioclase was much smaller, while the amount attached to quartz was negligible. This underlines the importance of the mineral surface charge for the attachment of $E$. coli (see also Section 2).

\subsection{Effect of grain surface roughness}

Bedbur (1989) and Gimbel and Sontheimer (1980) found that grain surface roughness influenced the collision efficiency to a certain extent. Photos taken with an electron microscope clearly showed that polystyrene colloids attached to edges, pinnacles, ridges, and other elements on the surface of grains. Also, concentrations of colloids were found in holes and excavations on the grain surface, probably due to a reduction of the flow velocity in the vicinity of these surface elements. And the attachment of colloids to flatter parts of the grain surface was markedly less. For larger colloids, like Cryptosporidium, Tufenkji et al. (2004) have reported that the shape of the individual grains can contribute significantly to the porous medium straining potential, as it may give rise to a very wide pore size distribution. However, the effect of grain surface roughness on the sticking efficiency of $E$. coli has not been studied, and no data are available.

\section{Evidence for bimodal sticking efficiencies}

Although data on E. coli are lacking, recent evidence suggests that filtration of microbial particles may not be consistent with the classical colloid filtration theory. Direct evidence for the non-exponential removal of microorganisms can be found by examining microbial deposition patterns in laboratory scale columns of uniform collector grains (Tufenkji et al., 2003). Redman et al. (2001) observed that the profile of retained viruses decayed according to a power-law. Li et al. (2004) utilized a log-normal distribution of deposition rate coefficients among the colloid population in order to simulate the effluent curves and retained profiles simultaneously. Simoni et al. (1998), by determining effluent concentrations of columns of various lengths, used two subpopulations of Pseudomonas strain B13, each with different collision efficiency. Tufenkji and Elimelech, 2004b, Tufenkji and Elimelech, 2005a and Tufenkji and Elimelech, 2005b also employed a similar type of dual deposition mode model in order to explain their polystyrene latex colloids and Cryptosporidium parvum oocysts retention profiles. In all of the abovementioned studies, the retained particle concentration profiles on semi-log scale resulted in an initial steep slope followed by a shallower slope (classical colloid filtration theory predicts one slope). However, the explanations for this non log-linear behavior offered by these authors differ somewhat. Li et al. (2004) attributed their decrease in deposition rate coefficient with transport distance to (1) distributed deposition rate coefficients, (2) straining at the influent end of the column, and (3) depletion of colloid concentration in the perimeter of the pores adjacent to grain surfaces due to deposition from solution. Li et al. (2004) calculated that the non log-linear retained particle concentrations could be explained if surface potentials determined for the polystyrene latex microspheres would show a variation of less than $0.5 \%$ and believed that this was a viable mechanism that could yield apparent decreases in deposition rate coefficients. 
Simoni et al. (1998) assumed two subpopulations of cells and attributed their non log-linear profiles to two distinct sticking efficiencies ( $a_{\text {fast }}$ and $\left.a_{\text {slow }}\right)$. Tufenkji and Elimelech, 2004b, Tufenkji and Elimelech, 2005a and Tufenkji and Elimelech, 2005b also gave three explanations for their non log-linear profiles: (1) based on Hahn's model (Hahn and O'Melia, 2004), a fraction of the particles has sufficient kinetic energy to escape from the secondary energy well and to remain in the fluid, (2) a fraction of the particle population overcomes the secondary energy barrier and reaches the primary energy well (resulting in distributed particle deposition rates), and (3) surface charge heterogeneities provide sites for fast and slow deposition and the concurrent existence of both favorable and unfavorable colloidal interactions in an otherwise homogeneous system can be described by considering a bimodal distribution.

Since the types of experiments described above have not been carried out with $E$. coli, it remains unknown whether non log-linear retention profiles also apply to $E$. coli. More future research on deposition patterns is required.

\section{Filter coefficients and collision efficiencies from field and laboratory experiments}

In Fig. 9 filter coefficients, grain sizes, and velocities of $E$. coli and thermotolerant coliforms from field and laboratory studies have been plotted together, with the grain size on the horizontal axis and the filter coefficient on the vertical axis. Data from field and laboratory studies are given as points (numbers refer to references given in the top right of the graph). The points were divided into four classes, based on pore water flow velocity (see legend). In a number of cases, only the type of soil (e.g. clayey loam) was mentioned in the reference. For these cases the US Soil Standards (Buol et al., 1989; Bell, 1987) were used in order to obtain an indication of the grain size. In one case, only one maximum breakthrough concentration was given (Caldwell, 1937). Also, sometimes pore water flow velocity was not measured or mentioned (see legend of Fig. 9: pore water flow velocity unknown). Finally, in none of the experiments were the die-off rate coefficients measured. In the laboratory experiments die-off was kept to a minimum or absent, and in most of the field experiments, transport was fast and therefore die-off was probably negligible. Die-off certainly played a role in longerterm field experiments (e.g. Caldwell, 1937; Dyer and Bhaskaran, 1943, Dyer and Bhaskaran, 1945a and Dyer and Bhaskaran, 1945b), but was not measured. For these reasons, the accuracy of the points in the figure is limited and they should be interpreted with care. However, the figure does illustrate a few interesting issues. Over the entire grain size and pore water flow velocity range, the filter coefficients varied between 0.1 and $20 \mathrm{~m}^{-1}$ only, and only in exceptional cases (Goldshmid et al., 1973; Sinton et al., 1997) did they fall outside this range. Furthermore, in some cases, low filter coefficients were found for soils with very small grain sizes $(<10 \mu \mathrm{m})$. In those cases, macropore flow must have taken place. Indeed, Smith et al. (1985), Hagedorn et al. (1978), Rahe et al. (1978), McCoy and Hagedorn, 1979 and McCoy and Hagedorn, 1980, Butler et al. (1954) all reported that macropore or pipe flow caused $E$. coli to be transported over considerable distances in short time intervals. Viraraghavan (1978) also observed fast transport, but he did not specifically refer to macropore flow. These studies were carried out in soils at shallow depth and macropore flow in soils is known to occur very frequently in the upper layers in which there is bioactivity. At the other end of the grain spectrum, similarly low filter coefficients were found at grain sizes between 0.1 and $1 \mathrm{~mm}$. Almost all of these studies were carried out in laboratory columns (indicated with an " $L$ " in Fig. 9) under ideal and completely controlled conditions. Between these two extremes, a variety of filter coefficients was measured-mainly in field experiments. 


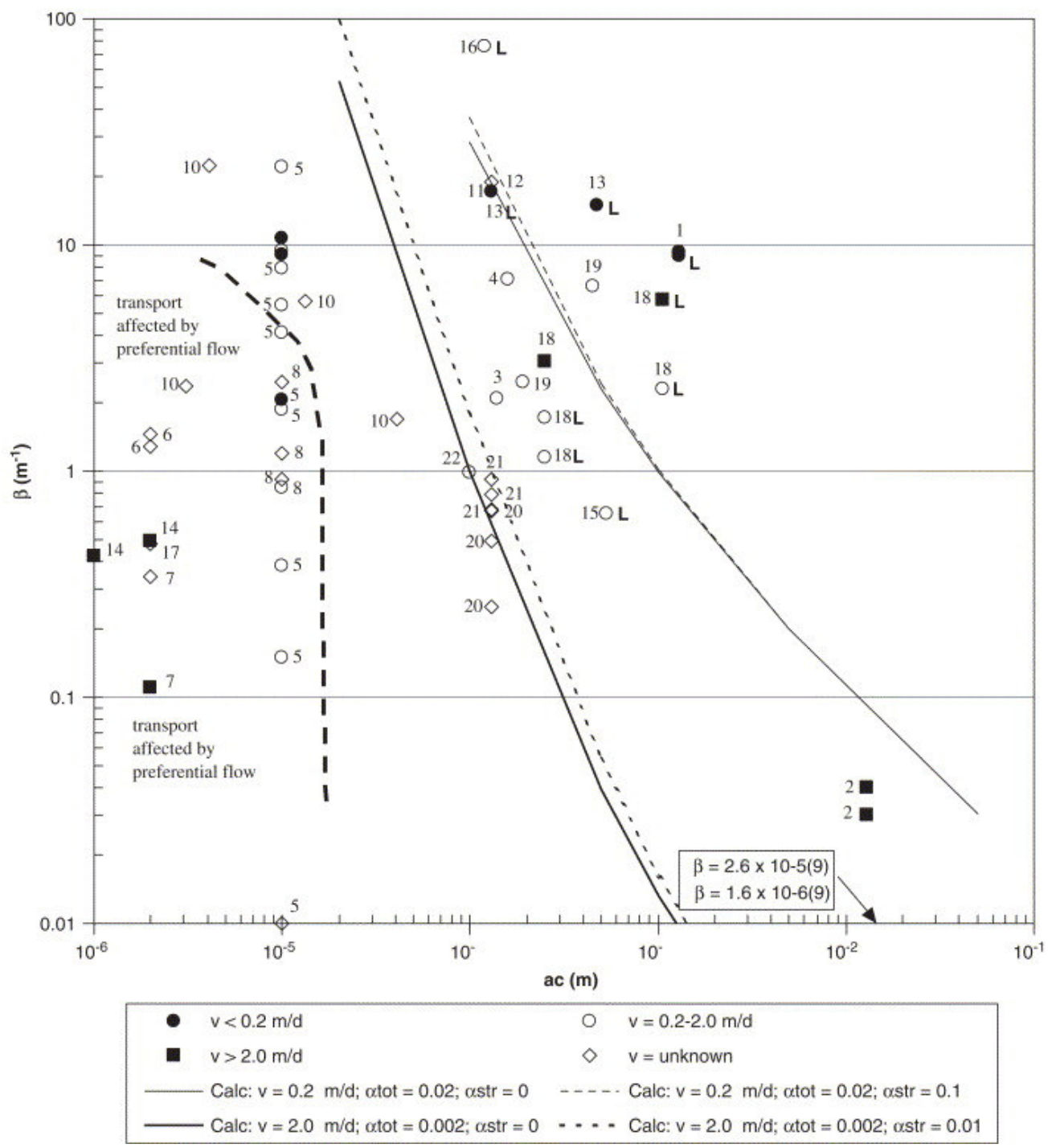

Fig. 9. Comparison of filter coefficients determined from field and laboratory studies and calculated filter coefficients. Parameters used to determine the calculated filter coefficients were $a=0.02-0.002, T=283 \mathrm{~K}, a_{\mathrm{p}}=2 \mu \mathrm{m}$, and $v=0.2$ $\left.2.0 \mathrm{~m} \mathrm{~d}^{-1}\right)$. See text for explanation. Parameters used to calculate filter coefficients were $T=283 \mathrm{~K}, a_{\mathrm{p}}=2 \mu \mathrm{m}, \varepsilon=0.3, H=6.5 \times 10^{-21} \mathrm{~J} ; \rho_{\mathrm{p}}=1050 \mathrm{~kg} \mathrm{~m}^{-3}$, $\rho_{\mathrm{fl}}=1000 \mathrm{~kg} \mathrm{~m}^{-3}, \pi=1.3 \times 10^{-3} \mathrm{~kg} \mathrm{~s} \mathrm{~m}^{-1}$; area left of bold dashed line: transport of $E$. coli and thermotolerant coliforms is influenced by preferential flow. (1. Pang et al., 2003; 2. Sinton et al., 1997; 3. Caldwell, 1937; 4. Dyer, 1943-1945; 5. Smith et al., 1985; 6. Hagedorn et al., 1978; 7. Rahe et al., 1978; 8. McCoy and Hagedorn, 1980; 9. Sinton et al., 2000; 10. Butler et al., 1954; 11. Schaub and Sorber, 1977; 12. Bouwer et al., 1974a and Bouwer et al., 1974b; 13. Stevik et al., 1999; 14. McCoy and Hagedorn, 1979; 15. Powelson and Mills, 2001; 16. Goldshmid et al., 1973; 17. Viraraghavan, 1978; 18. Hijnen et al., 2004; 19. Ziebell et al., 1975; 20. Reneau and Pettry, 1975; 21. Reneau, 1978; 22. Schijven, 2001). 
For grain sizes larger than $20 \mu \mathrm{m}$, pore water flow velocities could be roughly divided into two categories: $<0.2 \mathrm{~m} \mathrm{~d}^{-1}$ and between 0.2 and $2.0 \mathrm{~m} \mathrm{~d}^{-1}$. Using Eq. (21), we calculated a range of collision efficiencies, straining correction factors, and corresponding calculated filter coefficients (solid and dotted lines in Fig. 9) that, by trial and error, approximately fitted within the measured field filter coefficients. For $v=0.2 \mathrm{~m} / d$, the resulting $a_{\text {total }}$ was 0.02 , while the straining correction factor varied between 0 and 0.1 . For $v=2.0 \mathrm{~m} / d$, $a_{\text {total }}$ was 0.002 , while the straining correction factor varied between 0 and 0.01 . From this we concluded that the range of collision efficiencies determined for geochemically heterogeneous sediments under various hydrochemical conditions was small (0.002-0.2) compared with the sticking efficiency values from Fig. 5 (0.002-0.9, but mostly 0.01-0.9) for those solutions with typical groundwater ionic strength values (ranging from a few $\mathrm{mmol} \mathrm{L}^{-1}$ to several tens of $\mathrm{mmol} \mathrm{L}^{-1}$ ), especially given that divalent electrolytes (like $\mathrm{Ca}^{2+}, \mathrm{Mg}^{2+}$ ) are usually present in groundwater.

We think there are three possible explanations for the low sticking efficiencies that were estimated for the field studies:

(i) Preferential flow mechanisms, or the presence of zones of high permeability in which transport of bacteria is rapid, determine to a great extent the bacteria concentration at a certain distance from a source of pollution. If such zones are not identified by those doing the research, then calculated sticking efficiencies are underestimated, and actually are inappropriate to apply.

(ii) E. coli populations themselves may be heterogeneous in terms of their attachment characteristics and it might be that in each $E$. coli plume traveling through an aquifer, few will survive for a relatively long time and will not attach, giving rise to relatively low sticking efficiencies. In the laboratory, this population heterogeneity might be masked because of the relatively small scale of the experiments.

(iii) E. coli or thermotolerant coliforms usually travel in a plume of wastewater, consisting of many organic and inorganic compounds, all with highly variable concentrations and possibly affecting bacterial attachment characteristics. Laboratory experiments are usually carried out with solutions that do not reflect wastewater compositions.

\section{Kinetic desorption or detachment}

To date, there have been no systematic studies of the desorption or detachment of $E$. coli or thermotolerant coliforms previously attached to sediment grains. In the experiments carried out by Sinton et al. (2000), both E. coli 2690 and E. coli J6-2 concentrations during the so-called tailing phase of the breakthrough curve (which is thought to occur as a result of slow release or detachment of attached bacteria) decreased to zero. The same rapid reduction during the tailing phase has been found in thermotolerant coliforms (Sinton et al., 1997). In field-scale fractured rock tracer experiments, Champ and Schroeter (1988) reported that $E$. coli (wild type) concentrations during the tailing phase, most likely due to detachment, were at least 30 times lower than maximum $E$. coli concentration during peak breakthrough of the experiments. The detachment of $E$. coli as a process becomes more visible when relative concentrations are plotted on a log scale, (Johnson et al., 1995, Schijven, 2001). The difference between the maximum relative concentration during seeding with $E$. coli and immediately after seeding during the tailing phase in which desorption is taking place varies from 1 log-unit (Hijnen et al., 2004) to around 2-3 log-units (Peters, 1989; Hijnen et al., 
2004). From this we conclude that detachment occurs but it is relatively unimportant.

\section{Factors affecting inactivation}

\subsection{Effect of temperature}

The inactivation or die-off rate coefficients of bacteria in the fluid and bacteria attached to the sediment, $k_{i}$ and $k_{\text {is, }}$ are influenced by many factors (Murphy and Ginn, 2000; Reddy et al., 1981; Barcina et al., 1997). One of the most important factors is the temperature. In Fig. 10 the effect of temperature on the die-off rate coefficient of various $E$. coli strains is presented. However, the data are difficult and unwieldy to compare. The data are from "water" environments without sediment (except Sjogren, 1994; van Donsel et al., 1967; first graph of Bogosian et al., 1996) that were kept in the dark (except the second graph of Wang and Doyle, 1998; Korhonen and Martikainen, 1991; McFeters and Stuart, 1972) at a $\mathrm{pH}$ range of 6-8 (unknown for Rice et al., 1992; Nasser et al., 1993; van Donsel et al., 1967; McFeters and Stuart, 1972; Bogosian et al., 1996), usually in nonsterile, non-autoclaved conditions (except the first graph of Wang and Doyle, 1998; the second graph of Korhonen and Martikainen, 1991, second graph of Nasser et al., 1993; McFeters and Stuart, 1972). Despite the heterogeneous conditions during the various experiments, in the resulting data set the dependency of the die-off rate coefficients on temperature is similar: the increase in the die-off rate coefficient per degree Celsius rise is apparent and comparable in most experiments. If the experiments under sterile conditions are ignored and it is assumed that all other experimental variations are negligible, then the die-off rate coefficients are within a "band-width" of 1-log-unit. The average die-off coefficient at $10^{\circ} \mathrm{C}$ is $0.15 \mathrm{~d}^{-1}$ and at $20^{\circ} \mathrm{C}$ it is $0.50 \mathrm{~d}^{-1}$.
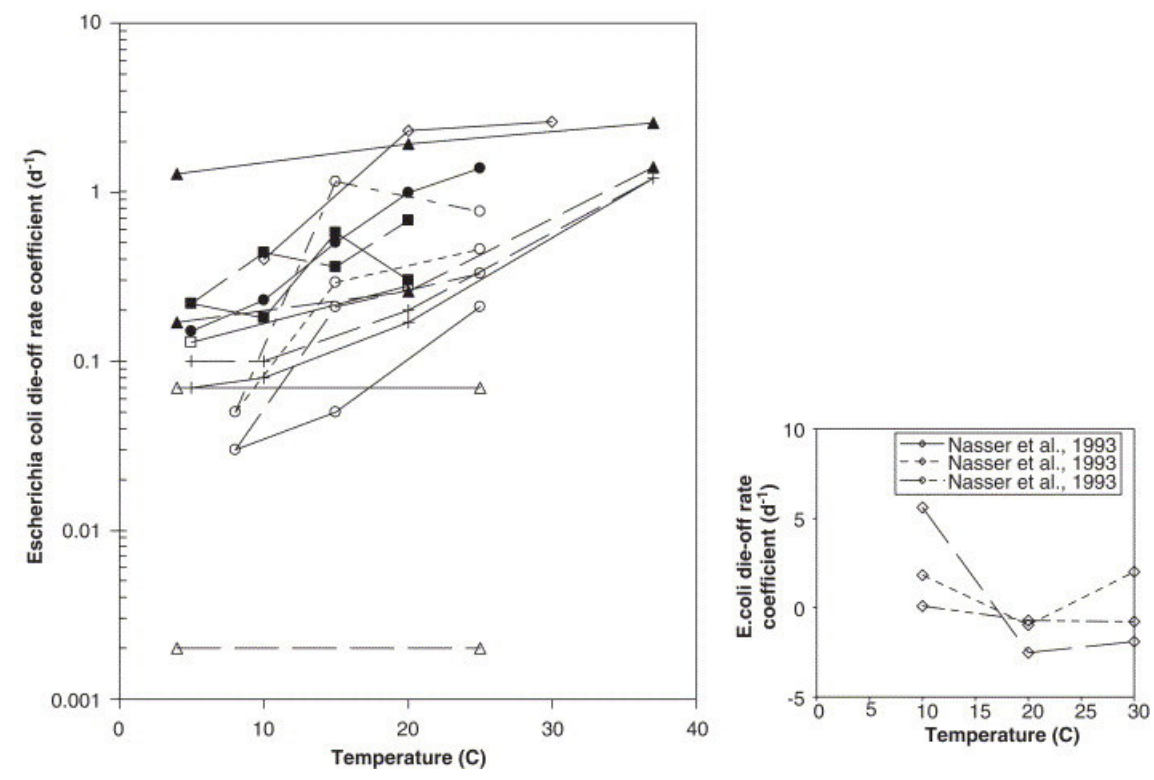

Fig. 10. Effect of temperature on the E. coli die-off rate coefficient. ( +- Sjogren, $1994 ;-$ - Sjogren, 1994; - -Rice et al., 1992; $\square$ Rice et al., 1992; - - Rice et al., 1992; - - Wang and Doyle, 1998; .....Wang and Doyle, 1998; - * Wang and Doyle, 1998; - o Wang and Doyle, 1998; $\triangle$ Korhonen and Martikainen, 1991;

$\triangle$ Korhonen and Martikainen, 1991; - Nasser et al., 1993; - Van Donsel et al., 1967; - Van Donsel et al., 1967; - McFeters and Stuart, 1972; Bogosian et al., 1996; - - Bogosian et al., 1996.) 


\subsection{Effect of protozoa and antagonists}

In Fig. 11 the effect of protozoa and/or antagonists on the die-off rate coefficient of various $E$. coli strains is presented. Protozoa may ingest and digest $E$. coli (predation), while antagonists such as indigenous bacteria compete for the same source of nutrients. In the figure each data pair is connected with a line, and the upper die-off rate coefficient represents non-autoclaved and non-sterile conditions in which predation and/or antagonism could take place, while the lower die-off rate coefficient has been determined for sterile conditions without predation/antagonism. From the data it can be concluded that due to predation/antagonism the die-off rate increases by 1 log-unit on average. Also, predation/antagonism does not seem to depend on temperature (Fig. 11).
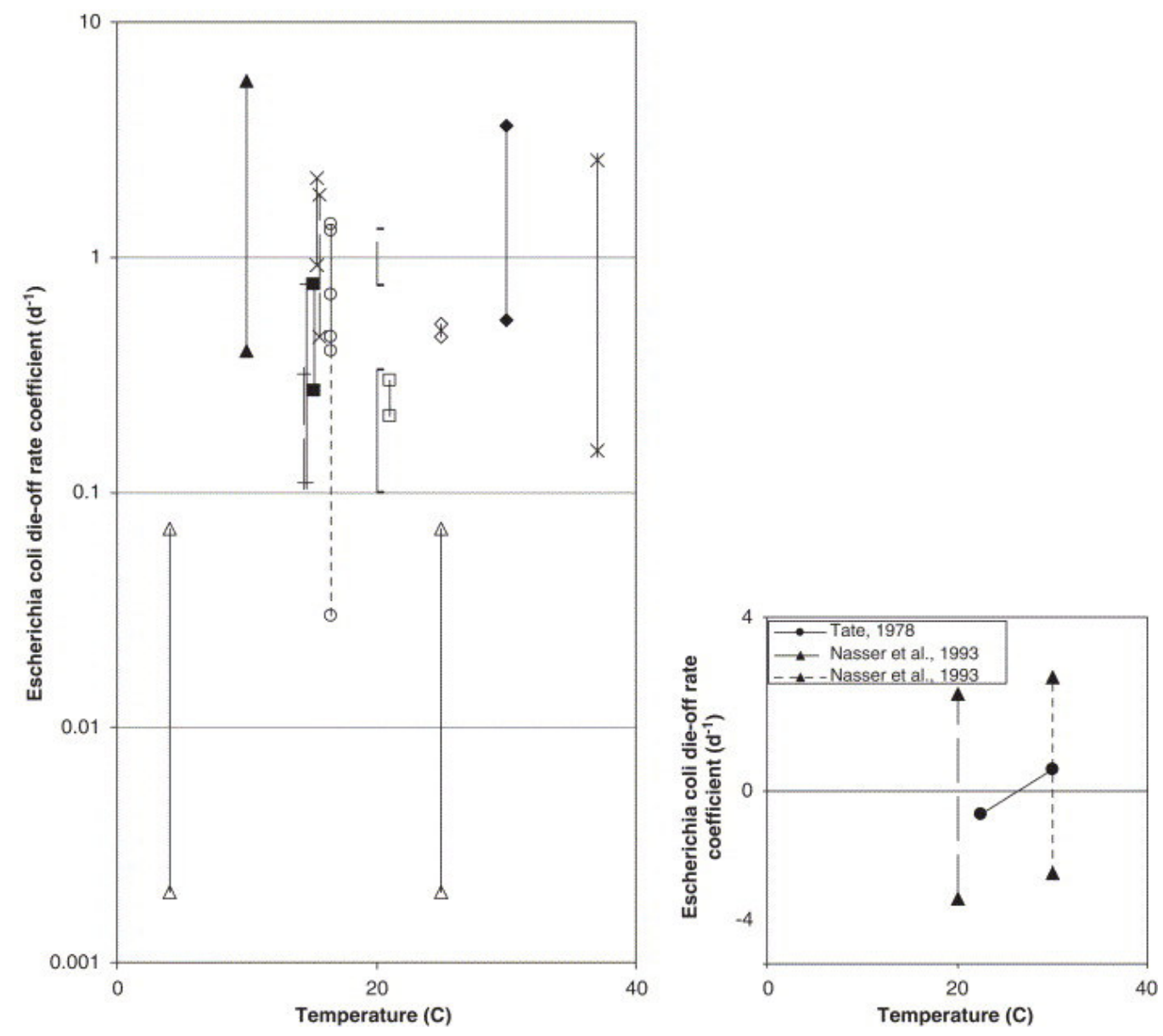

Fig. 11. Effect of autoclaving/sterilizing the medium prior to $E$. coli inoculation. (-... Artz and Killham, 2002; - - Artz and Killham, 2002; - Ramalho et al., 2001; - McCoy and Hagedorn, 1979; .......McCoy and Hagedorn, 1979; McCoy and Hagedorn, 1979; $\rightarrow$ Korhonen and Martikainen, 1991; $\triangle$ Korhonen and Martikainen, 1991; - Moreira et al., 1994; - Iriberri et al., 1994; - Nasser et al., 1993; - Chao and Feng, 1990; - × Gonzalez et al., 1992; ........ Gonzalez et al., 1992; - Bogosian et al., 1996; - Mitchell 1972, in: Althaus et al., 1982; - Mitchell 1972, in: Althaus et al., 1982.) 


\subsection{Other effects on the die-off rate coefficient}

In Table 2, a variety of "other" effects on the die-off rate coefficient are given. These are the effect of light, soil, $\mathrm{pH}$, toxic substances, and oxygen. The effect of light is not very relevant for groundwater conditions. Soil has the effect of increasing the die-off rate coefficient (Pang et al., 2003; Filip et al., 1986; Chao and Feng, 1990) or decreasing it (Karim et al., 2004b; Bogosian et al., 1996). The parameter "soil" incorporates several other effects (e.g. the presence of nutrients or toxic substances), and the effect of soil on the die-off rate coefficient depends very much on local conditions. The $\mathrm{pH}$ has a well-known effect on the die-off rate coefficient. McFeters and Stuart (1972) showed that in de-ionized water to which either potassium hydroxide or hydrochloric acid had been added, die-off rates were lowest in the $\mathrm{pH}$ range of 6-8. Allen et al. (1952; in: Althaus et al., 1982) demonstrated a similar phenomenon for $E$. coli in seawater. Heavy metals are known to have a toxic influence on bacteria (Althaus et al., 1982). Artz and Killham (2002) showed that the die-off rate of an E. coli O157:H7 strain in groundwater with a $[\mathrm{Cu}]$ of $3.91 \mathrm{mg} \mathrm{L}^{-1}$ was double that in groundwater with $0.61 \mathrm{mg} \mathrm{L}^{-1}$. Finally, Allen et al. (1952; in Althaus et al., 1982) showed that the die-off of $E$. coli in water saturated with oxygen was significantly lower than in water with a low oxygen saturation.

Table 2.

Effect of light, soil, $\mathrm{pH}$, toxic substances, and oxygen on the die-off rate coefficient of $E$. coli. Lower part of the table: additional E. coli die-off rate coefficients determined in single experiments (without testing the influence of certain parameters)

\begin{tabular}{|c|c|c|c|c|c|}
\hline Medium & $\begin{array}{c}T \\
\left({ }^{\circ} \mathrm{C}\right)\end{array}$ & pH & Strain & $\begin{array}{c}\text { Die-off } \\
\text { rate coeff. } \\
\left(d^{-1}\right)\end{array}$ & Reference \\
\hline \multicolumn{6}{|l|}{ Effect of light } \\
\hline Mineral water & 21 & & E. coli NCTC 9001 & 0.58 & Ramalho et al., 2001 \\
\hline Mineral water & 21 & & E. coli NCTC 9001 & 0.33 & idem; \\
\hline \multicolumn{6}{|l|}{ Effect of soil } \\
\hline $\begin{array}{l}\text { Native groundwater spiked } \\
\text { with raw sewage }\end{array}$ & 20 & 7 & $\begin{array}{l}\text { E. coli isolated } \\
\text { from sewage }\end{array}$ & $0.09-0.3$ & Pang et al., 2003 \\
\hline $\begin{array}{l}\text { Sorbed } E \text {. coli (to aquifer } \\
\text { material) }\end{array}$ & 20 & 7 & $\begin{array}{l}\text { E. coli isolated } \\
\text { from sewage }\end{array}$ & $2.59-4.47$ & idem; \\
\hline Groundwater & & & & 0.06 & Filip et al., 1986 \\
\hline Groundwater+mixed sand & & & & 0.09 & idem; \\
\hline Sterile tap water & 30 & & E. coli HB101 & 0.04 & Chao and Feng, 1990 \\
\hline Soil Chung Hsing University & 30 & & E. coli HB101 & 0.2 & idem; \\
\hline Wastewater Pima County & 22.5 & & $\begin{array}{l}\text { Thermotol. colif. } \\
\text { from WWTP }\end{array}$ & 0.62 & Karim et al., 2004b \\
\hline $\begin{array}{l}\text { Sediment WWTP Pima } \\
\text { County }\end{array}$ & 22.5 & & $\begin{array}{l}\text { Thermotol. colif. } \\
\text { from WWTP }\end{array}$ & 0.35 & idem; \\
\hline \multicolumn{6}{|l|}{ Effect of $p H$} \\
\hline $\begin{array}{l}\text { Deionized water with } \mathrm{KOH} \text { or } \\
\mathrm{HCl}\end{array}$ & 10 & 2.5 & E. coli $\mathrm{MH} 3427$ & 6.39 & $\begin{array}{c}\text { McFeters and Stuart, } \\
1972\end{array}$ \\
\hline $\begin{array}{l}\text { Deionized water with } \mathrm{KOH} \text { or } \\
\mathrm{HCl}\end{array}$ & 10 & 4 & E. coli $\mathrm{MH} 3427$ & 0.58 & idem; \\
\hline $\begin{array}{l}\text { Deionized water with } \mathrm{KOH} \text { or } \\
\mathrm{HCl}\end{array}$ & 10 & 5 & E. coli $\mathrm{MH} 3427$ & 0.4 & idem; \\
\hline $\begin{array}{l}\text { Deionized water with } \mathrm{KOH} \text { or } \\
\mathrm{HCl}\end{array}$ & 10 & 6 & E. coli $\mathrm{MH} 3427$ & 0.3 & idem; \\
\hline $\begin{array}{l}\text { Deionized water with } \mathrm{KOH} \text { or } \\
\mathrm{HCl}\end{array}$ & 10 & 7 & E. coli MH3427 & 0.32 & idem; \\
\hline $\begin{array}{l}\text { Deionized water with } \mathrm{KOH} \text { or } \\
\mathrm{HCl}\end{array}$ & 10 & 10 & E. coli MH3427 & 0.71 & idem; \\
\hline
\end{tabular}




\begin{tabular}{|c|c|c|c|c|c|}
\hline Medium & $\begin{array}{c}T \\
\left({ }^{\circ} \mathrm{C}\right)\end{array}$ & pH & Strain & $\begin{array}{l}\text { Die-off } \\
\text { rate coeff. } \\
\left(d^{-1}\right)\end{array}$ & Reference \\
\hline $\begin{array}{l}\text { Deionized water with } \mathrm{KOH} \text { or } \\
\mathrm{HCl}\end{array}$ & 10 & 12 & E. coli $\mathrm{MH} 3427$ & 6.39 & idem; \\
\hline Seawater & 20 & 5.2 & E. coli & 0.28 & $\begin{array}{l}\text { Allen et al., 1952, in: } \\
\text { Althaus et al., } 1982\end{array}$ \\
\hline Seawater & 20 & 6.1 & E. coli & 0.42 & idem; \\
\hline Seawater & 20 & 7.1 & E. coli & 0.42 & idem; \\
\hline Seawater & 20 & 7.7 & E. coli & 0.33 & idem; \\
\hline $\begin{array}{l}\text { Pompano fine sand, approx. } \\
\text { saturated }\end{array}$ & 30 & 6.64 & E. coli ATCC 15597 & 0.59 & Tate, 1978 \\
\hline $\begin{array}{l}\text { Sterile Pahokee Muck (soil), } \\
\text { approx. saturated }\end{array}$ & 22.5 & 6.16 & E. coli ATCC 15597 & 0.04 & idem; \\
\hline \multicolumn{6}{|l|}{ Effect of toxic substances } \\
\hline $\begin{array}{l}\text { Well water } 4 \\
\left(\mathrm{Cu}=0.61 \mathrm{mg} \mathrm{L}^{-1}\right)\end{array}$ & 15 & 7.13 & O157:H7 & 0.77 & $\begin{array}{l}\text { Artz and Killham, } \\
2002\end{array}$ \\
\hline $\begin{array}{l}\text { Well water } 3 \\
\left(\mathrm{Cu}=3.91 \mathrm{mg} \mathrm{L}^{-1}\right)\end{array}$ & 14.8 & 6.98 & O157:H7 & 1.59 & idem; \\
\hline \multicolumn{6}{|l|}{ Effect of oxygen } \\
\hline $\begin{array}{l}0.003 \mathrm{M} \text { phosphate buffer } \\
(1-18 \% \text { O2 saturation) }\end{array}$ & & 6 & E. col & 0.58 & $\begin{array}{l}\text { Allen et al., 1952, in: } \\
\text { Althaus et al., 1982 }\end{array}$ \\
\hline $\begin{array}{l}0.003 \text { M phosphate buffer } \\
\text { (100\% O2 saturation) }\end{array}$ & & 6 & E. coli & 0.09 & $\begin{array}{l}\text { Allen et al., 1952, in: } \\
\text { Althaus et al., 1982 }\end{array}$ \\
\hline \multicolumn{6}{|l|}{ Effect of water type } \\
\hline Tap water from Coimbra & 25 & & E. coli ATCC 8677 & 0.08 & Moreira et al., 1994 \\
\hline Mineral water (glass bottles) & 25 & 5.64 & E. coli ATCC 8677 & 0.35 & idem; \\
\hline \multicolumn{6}{|l|}{ Other } \\
\hline Groundwater & 20 & & E. coli & 0.12 & Kudryavtseva, 1972; \\
\hline Groundwater & 20 & & E. coli-408 & 0.16 & idem; \\
\hline Well water & 11 & 7.48 & Thermotol. colifom & 0.77 & McFeters et al., 1974 \\
\hline $\begin{array}{l}\text { Rural domestic well } 275 \mathrm{ft} \text { in } \\
\text { depth }\end{array}$ & 9 & 7.8 & E. colistrain $\mathrm{Hfr}$ & 0.74 & Keswick et al., 1982 \\
\hline Gainesville water well & 22 & 7.6 & $\begin{array}{l}\text { E. coli stock } \\
\text { collection }\end{array}$ & 0.4 & Bitton et al., 1983 \\
\hline Infiltrated sewage effluent & & & Total coliform & 0.03 & idem; \\
\hline Infiltrated sewage effluent & & & $\begin{array}{l}\text { Thermotolerant } \\
\text { coliform }\end{array}$ & 0.06 & idem; \\
\hline Sterile well water & 22.5 & & E. coli ED 8654 & 0.01 & Caldwell et al., 1989 \\
\hline Sterile well water & 22.5 & & E. coli HB 101 & 0.02 & idem; \\
\hline
\end{tabular}

\section{Modeling the removal of $E$. coli}

To illustrate the effect of a number of key parameters on the transport of $E$. coli in aquifers, a steady state (for the flow field) groundwater model was constructed in MODFLOW (Webtech360, 2003). The area modeled was $500 \times 500 \mathrm{~m}$ and the model consisted of 100 columns, 100 rows, and 2 isotropic homogeneous layers (the top layer was $5 \mathrm{~m}$ thick and the bottom layer was $15 \mathrm{~m}$ thick) each with a permeability of $20 \mathrm{~m} \mathrm{~d}^{-1}$ and a porosity of 0.25 . In the middle of the model, in layer 2, an abstraction well was located with an abstraction rate of $2000 \mathrm{~m}^{3} \mathrm{~d}^{-1}$; $100 \mathrm{~m}$ west of this well, in layer 1 a small recharge well was located with a recharge rate of $1 \mathrm{~m}^{3} \mathrm{~d}^{-1}$ to simulate the effect of a cesspit dug into the saturated zone. The $E$. coli concentration of the recharging water was $10^{6}$ cells $(\mathrm{mL})^{-1}$, which was thought to be representative of high-strength sewage (Sawyer et al., 1994).

The first step was to calculate the pore water flow velocities in each $5 \times 5 \mathrm{~m}$ cell. With this flow field, a total retention rate coefficient was calculated based on the assumption that detachment is negligible. Therefore inactivation of sorbed cells became irrelevant and only the mass balance of bacteria in the liquid phase was considered. Then, Eq. (11) can be rewritten as 


$$
\frac{d S}{d t}=m_{p}^{2}\left(k_{1}+k_{s i 1}\right) C
$$

and inserting in Eq. (1):

$$
\frac{d C}{d t}=\nabla \cdot(D V C)-\nabla \cdot(v C)-k_{i_{1}+1} C
$$

in which $k_{\text {total }}$ is the total retention rate coefficient (now expressed in $\mathrm{d}^{-1}$ instead of $\mathrm{m} \mathrm{d}^{-1}$ ), which includes the effect of favorable and unfavorable attachment (Eq. (13)) as well as straining and die-off or inactivation and is defined as

$$
k_{a 11}=\frac{f_{v}}{4}\left|\eta_{0} z_{a 1}+\eta_{s} z_{s i}\right|+k_{\mathrm{i}}
$$

The SCCE, $\eta_{0}$, was determined with Eq. (15). Temperature, unfavorable collision efficiency, favorable collision efficiency, straining correction parameter, and the inactivation rate coefficient were kept constant. The $k$-value fields are given in Fig. 12 for an aquifer consisting of quartz grains (left-hand part) and an aquifer consisting of quartz sand with Fe-oxyhydroxides (1.5\% of the total surface area; right-hand part of Fig. 12). Per type of aquifer, the grain size was varied (1 mm and $5 \mathrm{~mm})$, as was the size of the infiltrating $E$. coli $(1$ and $3 \mu \mathrm{m})$. Fig. 12 shows that within these boundary conditions, the $k_{\text {total }}$ varied from 0.1 on the boundaries of the model where flow velocities were lowest, to a maximum of 0.373 for the quartz-grained aquifer near the abstraction well where pore water flow velocities were highest. The maximum $k_{\text {total }}$ for the Fe-coated aquifer was $0.916 \mathrm{~d}^{-1}$. From the figure, the following general observations can be made:

- In coarse-grained aquifers the total retention rate coefficient is dominated by decay (here taken at "only" $0.1 \mathrm{~d}^{-1}$ ) while physicochemical removal processes are of secondary importance;

- When the grain size reduces (the difference between middle $k$-value field and the upper $k$-value fields), then the total retention rate coefficient increases due to an increase in the diffusion, interception, and straining components in the SCCE. Of these, the total retention rate increase due to diffusion is the most pronounced;

- When the size of the colloid increases (compare the uppermost and lowest $k$ value fields), then the total retention rate coefficient increases due to an increase of the sedimentation, the interception, and the straining component in the SCCE. Of these, the total retention rate increase due to sedimentation is most pronounced. 

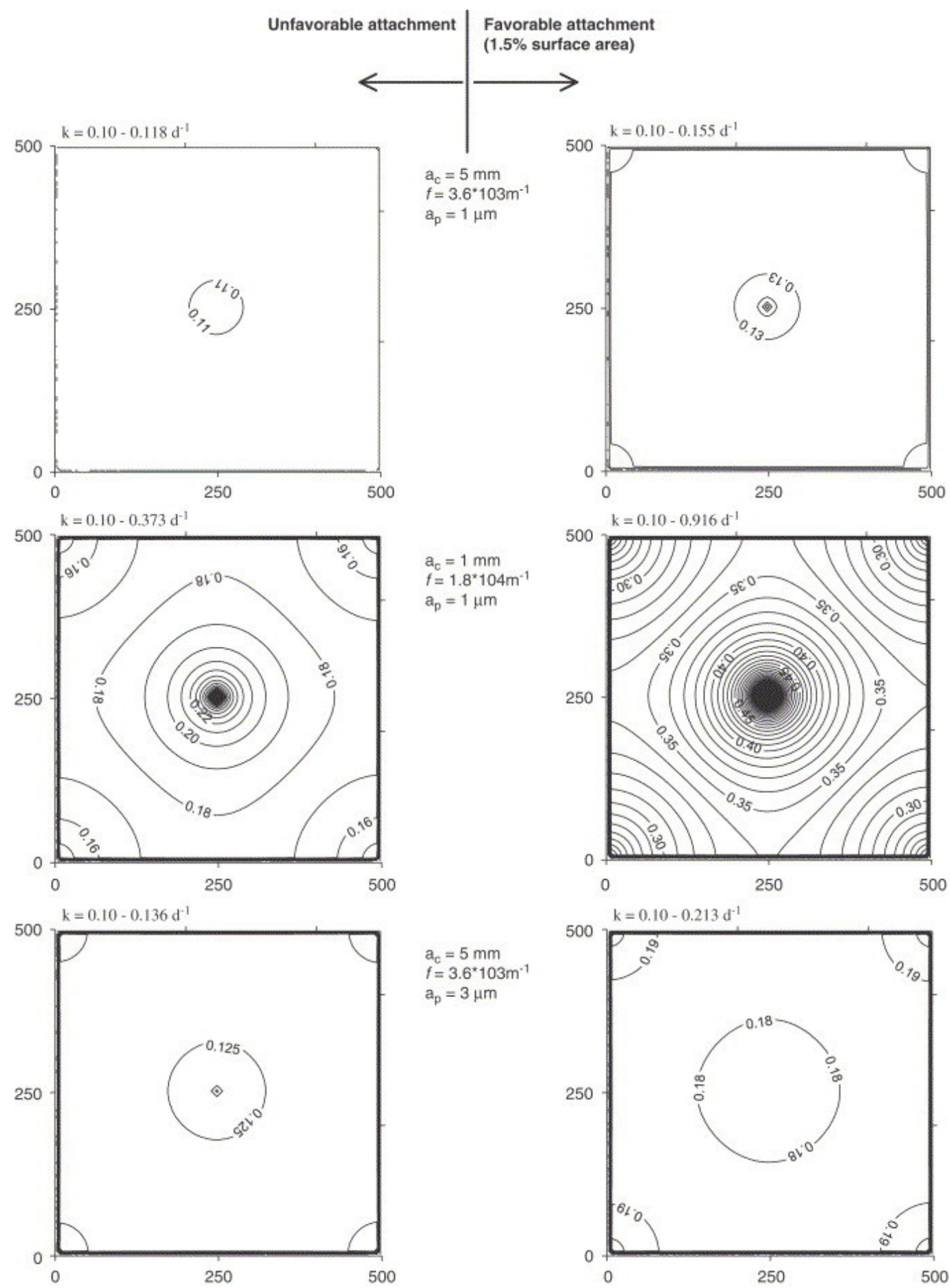

Fig. 12. Calculated total retention rate coefficient $k_{\text {total }}$ (contour line interval: $0.01 \mathrm{~d}^{-1}$ ). See text for explanation. Parameters used were $a_{\text {unfav }}=0.007$, $a_{\mathrm{fav}}=1.00, a_{\mathrm{str}}=0.01, k_{\mathrm{i}}=0.1 \mathrm{~d}^{-1}, T=283 \mathrm{~K}, \varepsilon=0.25, H=6.5 \times 10^{-21} \mathrm{~J}$; $\rho_{\mathrm{p}}=1050 \mathrm{~kg} \mathrm{~m}^{-3}, \rho_{\mathrm{fl}}=1000 \mathrm{~kg} \mathrm{~m}^{-3}, w=1.3 \times 10^{-3} \mathrm{~kg} \mathrm{~s} \mathrm{~m}^{-1}$; left-hand graphs: $\lambda=0$, right-hand graphs: $\lambda=0.015$. 
Finally, in MT3DMS (Zeng and Wang, 1999) the E. coli concentration in the Fecoated aquifer was determined over time (Fig. 13), using the right-hand side $k$ value fields of Fig. 12. The dispersivity used was $10 \mathrm{~m}$. The distribution of concentration in the second layer was at a dynamic equilibrium some 60 days after the start of infiltration of $E$. coli (the situation after 100 days is shown in Fig. 13). The maximum distance traveled from the recharge well in these three cases as a result of advection including dispersion on the one hand and total retention on the other is around $80 \mathrm{~m}$ in the coarse-grained aquifer with the small $E$. coli $(1 \mu \mathrm{m})$. In the fine-grained aquifer, the maximum distance traveled is only a few meters, while in the coarse-grained aquifers with large $E$. coli $(3 \mu \mathrm{m})$, it is around $60 \mathrm{~m}$.
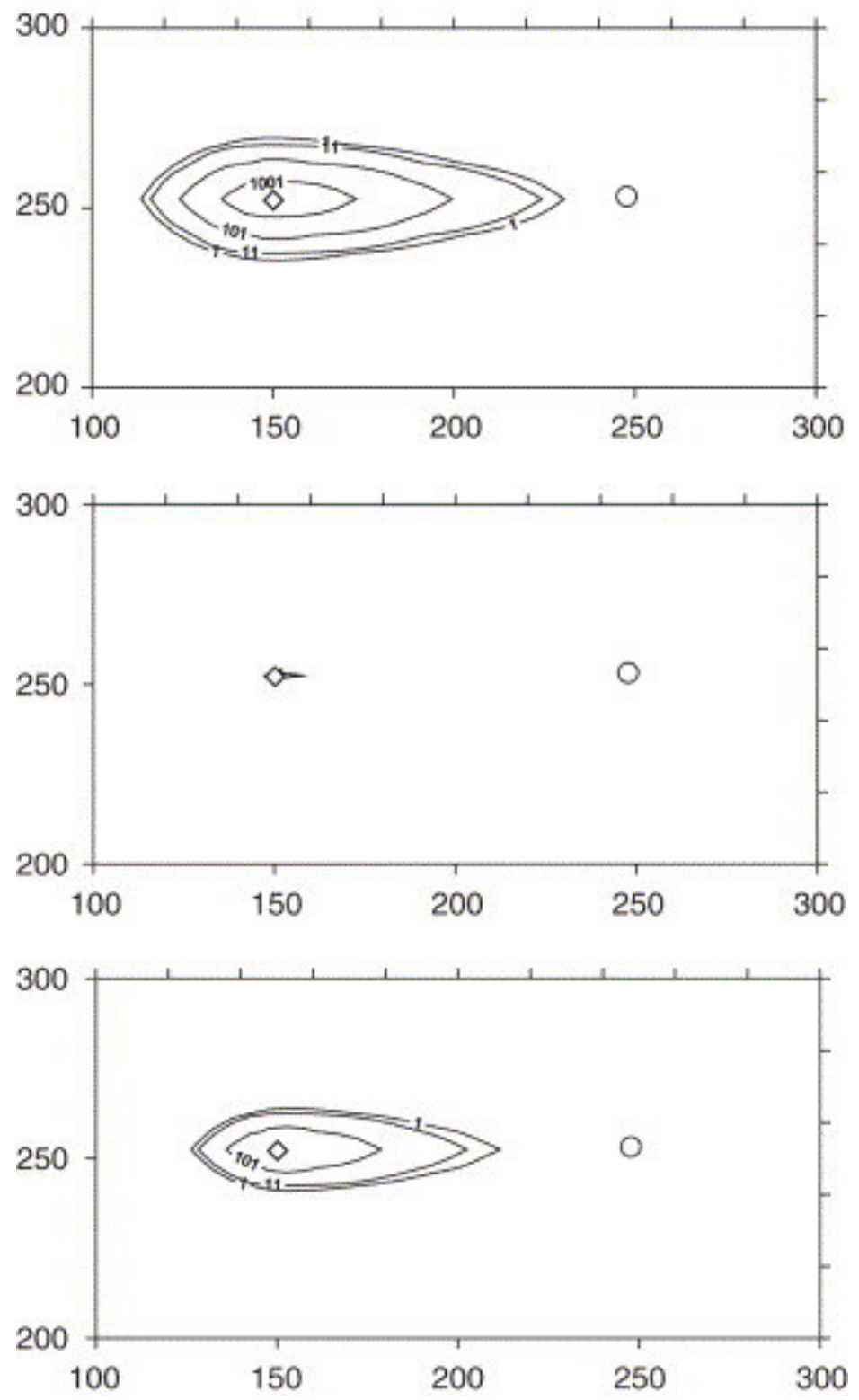

Fig. 13. Distribution of $E$. coli concentration (in cells $(\mathrm{mL})^{-1}$ ) midway in layer 2 at a depth of $12.5 \mathrm{~m}$ after 100 days of infiltration. The abstraction well is given as a circle and the recharge well is a diamond (the recharge well is located in the middle of layer 1 at a depth of $2.5 \mathrm{~m}$ ). Retention rate coefficients used are given in Fig. 12 (right-hand part) for the case of favorable attachment. 


\section{Conclusions}

From this literature review, a number of important conclusions emerge:

Under fully controlled laboratory conditions, with constant chemical groundwater quality, one type of collector (quartz grains), a range of Darcy flow velocities, and a range of collector grain sizes, there was reasonable agreement between the measured filter coefficients from breakthrough curves and the filter coefficients calculated using the SCCE (determined with the TE correction equation). Therefore, we conclude that colloid filtration theory in general and the TE correction equation in particular provide a valuable framework for predicting the transport of $E$. coli in porous media under saturated conditions. The bacterial transport mechanism due to straining is not yet fully understood. Although theoretical relations and experimental data appear to be in agreement, the identity of the straining correction parameter remains obscure.

One of the most important factors determining the total sticking efficiency of $E$. coli in sediment is surface charge difference between collector and $E$. coli. These charge differences depend on the solution chemistry, ionic strength, geochemical heterogeneity, bacteria population heterogeneity, and the composition of lipopolysaccharides on the outer membrane of $E$. coli. In quartz-grain dominated sediments without preferential flow with an average groundwater composition consisting of monovalent and divalent ions such as $\mathrm{Na}, \mathrm{K}, \mathrm{Ca}$, and $\mathrm{Mg}$ with a total concentration of $<20 \mathrm{mmol} \mathrm{L}^{-1}$, the sticking efficiency values of $E$. coli (consisting of an O-antigen shielding the charged phosphate groups of the inner core oligosaccharide of the outer membrane) may vary between 0.02 and 0.9 . When positively charged minerals are present as patches around sediment grains or as separate grains, there will be increased attachment. Another factor of importance in determining the total sticking efficiency of $E$. coli might be grain surface roughness. However, to date this has not been studied and so no data are available.

The range of field sticking efficiencies determined for geochemically heterogeneous sediments under various hydrochemical conditions was low (0.002-0.2) compared with laboratory sticking efficiencies (0.02-0.9). There are three possible explanations for this: (i) preferential flow mechanisms, or the presence of zones of high permeability in which transport of bacteria is rapid, may largely determine the bacterial concentration at a certain distance from a source of pollution, (ii) E. coli populations themselves may be heterogeneous in terms of their attachment characteristics, i.e. a fraction of the $E$. coli cells may have low sticking efficiencies, (iii) E. coli or thermotolerant coliforms usually travel in a plume of wastewater, consisting of many organic and inorganic compounds, all with highly variable concentrations. These compounds may block attachment sites, thereby leading to enhanced transport of $E$. coli. Laboratory experiments are usually carried out with solutions that do not reflect wastewater compositions, which might be the cause for the observed discrepancy between laboratory and field sticking efficiencies.

The detachment of $E$. coli has not been studied systematically. However, from the few cases in which deloading of $E$. coli was visible from breakthrough curves, the maximum relative $E$. coli concentrations were 1-3 log-units lower than during loading. This shows that detachment occurs, but as a process it is relatively unimportant.

The inactivation or die-off rate coefficients of $E$. coli and thermotolerant coliforms in solution and attached to sediment are influenced by many factors. The two 
major factors seem to be temperature and the presence of predators. The average die-off coefficient at $10^{\circ} \mathrm{C}$ is $0.15 \mathrm{~d}^{-1}$ and increases to $0.50 \mathrm{~d}^{-1}$ at $20^{\circ} \mathrm{C}$. However, these rate coefficients are extremely variable. Predation causes the dieoff rate coefficient to increase by 1 log-unit on average.

In our opinion, an important area of research on the transport of $E$. coli in aquifers is the effect of typical wastewater characteristics on the transport of $E$. coli and thermotolerant coliforms. These characteristics include high ionic strength values, high concentrations of organic compounds (e.g. aromatic and aliphatic carbohydrates and humic substances), and the presence of high concentrations of other microorganisms. How do $E$. coli and thermotolerant coliform organisms behave under these conditions in terms of sticking efficiency, attachment rate, and detachment rate coefficients, survival, and, more generally, in terms of the ability of these pathogens to be transported through aquifers? Little is known about the transport behavior of $E$. coli under those conditions, yet leakage of wastewater is one of the most important sources of $E$. coli and pathogens found in groundwater.

Finally, the upscaling of data obtained from controlled experiments in the laboratory to typical field conditions needs due attention. If preferential flow occurs, then which factors are most important in determining $E$. coli transport behavior, how should those characteristics be incorporated into the conceptualization of an E. coli transport model, and which of the existing models describing preferential flow (e.g. dual porosity, dual permeability, multi-porosity, and/or multi-permeability; Šimùnek et al., 2003) is relevant? In addition to the conceptualization of an $E$. coli transport model under field conditions, attention needs to be given to the aspect of population heterogeneity of $E$. coli and thermotolerant coliforms perhaps resulting in varying (decreasing) sticking efficiencies along the flow path in order to arrive at a better framework for predicting fecal indicator organism concentrations in aquifers.

\section{Acknowledgments}

This project was funded by the UNESCO-IHE Institute for Water Education. Thanks are due to the staff of the UNESCO-IHE laboratories for their support. Joy Burrough and Prof. Dr. Gary Amy advised on the English.

\section{References}

Alexander and Seiler, 1983 Alexander, I., Seiler, K.P., 1983. Lebensdauer und Transport von Bakterien in Typischen Grundwasserleitern. Münchener Schotterebene. DVGW-Schr., 35, pp. 113-125 (ZfGW, Franfurt/Main).

Althaus et al., 1982 Althaus, H., Jung, K.D., Matthess, G., Pekdeger, A., 1982. Lebensdauer von Bacterien und Viren in Grundwasserleitern. Umweltbundesamt, Materialien 1/82. Schmidt-Verlag, Berlin.

Amor et al., 2000 K. Amor, D.E. Heinrichs, E. Frirdich, K. Ziebell, R.P. Johnson and C. Whitfield, Distribution of core oligosaccharide types in lipopolysaccharides from Escherichia coli, Infect. Immun. 68 (2000) (3), pp. 1116-1124.

Appelo and Postma, 1993 C.A.J. Appelo and D. Postma, Geochemistry, Groundwater and Pollution, A.A. Balkema, Rotterdam (1993). 
Arana et al., 2004 I. Arana, C. Seco, K. Epelde, A. Muela, A. Fernandez-Astorga and I. Barcina, Relationships between Escherichia coli cells and the surrounding medium during survival processes, Antonie van Leeuwenhoek 86 (2004), pp. 189-199.

Artz and Killham, 2002 R.R.E. Artz and K. Killham, Survival of Escherichia coli O157:H7 in private drinking water wells: influences of protozoan grazing and elevated copper concentrations, FEMS Microbiol. Lett. 216 (2002), pp. 117-122.

AWWA, 1999 AWWA, 1999. Waterborne Pathogens. American Water Works Association Manual of Water Supply Practices AWWA M48. ISBN 1-58321-022-9.

Barcina et al., 1997 I. Barcina, P. Lebaron and J. Vives-Rego, Survival of allochthonous bacteria in aquatic systems: a biological approach, FEMS Microbiol. Ecol. 23 (1997), pp. 1-9.

Bedbur, 1989 E. Bedbur, Laboruntersuchungen zum Einfluss sedimentologischer und hydraulischer Parameter auf die Filterwirkung gleichförmiger Sande, Verichte-Reports, Geol.-Paläont. Inst. Univ. Kiel 31 (1989), pp. 1-77.

Bell, 1987 Bell, F.G., 1987. Ground Engineer's Reference Book. Butterworth and Co Ltd. ISBN 0-40801173-4.

Bergey et al., 1984 Bergey, D.H., Holt, J.G., Krieg, N.R., 1984. Bergey's Manual of Systematic Bacteriology. Williams \& Wilkins, Baltimore, USA. ISBN 0-683-04108-8.

Bitton et al., 1983 G. Bitton, S.R. Farrah, R.H. Ruskin, J. Butner and Y.J. Chou, Survival of pathogenic and indicator organisms in ground water, Ground Water 21 (1983), pp. 405-410.

Bitton and Harvey, 1992 Bitton, G., Harvey, R.W., 1992. Transport of pathogens through soils and aquifers. In: Mitchell, R. (Ed.), Environmental Microbiology, ISBN 0-471-50647-8, pp. 103-124.

Bhattacharjee et al., 2002 S. Bhattacharjee, J.N. Ryan and M. Elimelech, Virus transport in physically and geochemically heterogeneously subsurface porous media, J. Cont. Hydrol. 57 (2002), pp. 161187.

Bogosian et al., 1996 G. Bogosian, L.E. Sammons, P.J.L. Morris, J.P. O'Neill, M.A. Heitkamp and D.B. Webber, Death of Escherichia coli K-12 strain W3110 in soil and water, Appl. Environ. Microbiol. 62 (1996), pp. 4114-4120.

Bouwer et al., 1974a H. Bouwer, J.C. Lange and M.S. Riggs, High-rate land treatment I: infiltration and hydraulic aspects of the Flushing Meadows project, J. Water Poll. Cont. Fed. 46 (1974), pp. 834 843.

Bouwer et al., 1974b H. Bouwer, J.C. Lange and M.S. Riggs, High-rate land treatment II: water quality and economic aspects of the Flushing Meadows project, J. Water Poll. Cont. Fed. 46 (1974), pp. 844859.

Bradford and Bettahar, 2005 S.A. Bradford and M. Bettahar, Straining, attachment, and detachment of Cryptosporidium Oocysts in saturated porous media, J. Environ. Qual. 34 (2005), pp. 469-478.

Bradford et al., 2002 S.A. Bradford, S.R. Yates, M. Bettahar and J. Simunek, Physical factors affecting the transport and fate of colloids in saturated porous media, Water Resour. Res. 38 (2002) (12), p. 1327.

Bradford et al., 2003 S.A. Bradford, J. Simunek, M. Bettahar, M.T. van Genuchten and S.R. Yates, Modeling colloid attachment, straining, and exclusion in saturated porous media, Environ. Sci. Technol. 37 (2003), pp. 2242-2250.

Buol et al., 1989 Buol, S.W., Hole, F.D., McCracken, R.J., 1989. Soil Genesis and Classification. Iowa State University Press. ISBN 0-8138-1462-6.

Butler et al., 1954 R.G. Butler, G.T. Orlob and P.H. McGauhey, Underground movement of bacterial and chemical pollutants, J. Am. Water Works Assoc. 46 (1954), pp. 97-111. 
Caldwell, 1937 E.L. Caldwell, Pollution flow from pit latrines when an impervious stratum closely underlies the flow, J. Infect. Dis. 61 (1937), pp. 270-288.

Caldwell et al., 1989 B.A. Caldwell, C. Ye, R.P. Griffiths, C.L. Moyer and R.Y. Morita, Plasmid expression and maintenance during long-term starvation-survival of bacteria in well water, Appl. Environ. Microbiol. 55 (1989), pp. 1860-1864.

Champ and Schroeter, 1988 D.R. Champ and J. Schroeter, Bacterial transport in fractured rock-A field-scale tracer test at the Chalk River Nuclear Laboratories, Water Sci. Technol. 20 (1988), pp. 8187.

Chao and Feng, 1990 W.L. Chao and R.L. Feng, Survival of genetically engineered Escherichia coli in natural soil and river water, J. Appl. Bacteriol. 68 (1990), pp. 319-325.

Corapcioglu and Haridas, 1984 M.Y. Corapcioglu and A. Haridas, Transport and fate of microorganisms in porous media: a theoretical investigation, J. Hydrol. 72 (1984), pp. 149-169.

Corapcioglu and Haridas, 1985 M.Y. Corapcioglu and A. Haridas, Microbial transport in soils and groundwater: a numerical model, Adv. Water Resour. 8 (1985), pp. 188-200.

Crane and Moore, 1984 S.R. Crane and J. Moore, Bacterial pollution of groundwater: a review, Water Air Soil Pollut. 22 (1984), pp. 67-83.

Daubner, 1975 I. Daubner, Changes in the Properties of Escherichia coli under the influence of water environments, Internationale Vereinigung fur Limnologie Verhandlungen 19 (1975), pp. 2650-2657.

De Kerchove and Elimelech, 2005 A.J. De Kerchove and M. Elimelech, Relevance of electrokinetic theory for 'soft' particles to bacterial cells: implications for bacterial adhesion, Langmuir 21 (2005), pp. 6462-6472.

De Marsily, 1986 G. De Marsily, Quantitative Hydrology, Academic Press, San Diego (1986) ISBN 012-208916-2.

Dyer and Bhaskaran, 1943 B.R. Dyer and T.R. Bhaskaran, Investigation of groundwater pollution, Part I: determination of the direction and the velocity of flow of groundwater, Ind. J. Med. Res. 31 (1943), pp. 231-243.

Dyer and Bhaskaran, 1945a B.R. Dyer and T.R. Bhaskaran, Investigation of groundwater pollution, Part II: soil characteristics in West-Bengal, India, at the site of groundwater pollution investigations, Ind. J. Med. Res. 33 (1945), pp. 17-22.

Dyer and Bhaskaran, 1945b B.R. Dyer and T.R. Bhaskaran, Investigation of groundwater pollution, Part III: groundwater pollution in West Bengal, India, Ind. J. Med. Res. 33 (1945), pp. 23-62.

Elimelech et al., 2000 M. Elimelech, M. Nagai, C.-H. Ko and J. Ryan, Relative insignificance of mineral zeta potential to colloid transport in geochemically heterogeneous porous media, Environ. Sci. Technol. 34 (2000), pp. 2143-2148.

Filip et al., 1986 Filip, Z., Dizer, H., Kaddu-Mulinda, D., Kiper, M., Lopez-Pila, J.M., Milde, G., Nasser, A., Seidel, K., 1986. Untersuchungen über das Verhalten pathogener und anderer Mikroorganismen und Viren im Grundwasser im Hinblick auf die Bemessung von Wasserschutzzonen. Institut für Wasser-, Boden- und Lufthygiene des Bundesgesundheitsamtes. Berlin, 1986 (WaBoLu-Hefte 3/1986).

Foppen, 2002 J.W.A. Foppen, Impact of high-strength wastewater infiltration on groundwater quality and drinking water supply: the case of Sana'a, Yemen J. Hydrol. 263 (2002), pp. 198-216.

Foppen and Schijven, 2005 J.W.A. Foppen and J.F. Schijven, Transport of Escherichia coli in columns of geochemically heterogeneous sediment, Water Res. 39 (2005), pp. 3082-3088.

Foppen et al., 2005 J.W.A. Foppen, A. Mporokoso and J.F. Schijven, Determining straining of Escherichia coli from breakthrough curves, J. Contam. Hydrol. 76 (2005), pp. 191-210. 
Foster and S.S.D., 2000 Foster, S.S.D., 2000. Groundwater resources at the turn of the millennium: taking stock and looking forward. In: Sillo et al. (Eds.), Groundwater: Past Achievements and Future Challenges, Balkema, Rotterdam, The Netherlands, ISBN 9058091597.

Gaboriaud and Ehrhardt, 2003 F. Gaboriaud and J.-J. Ehrhardt, Effects of different crystal faces on the surface charge of colloidal goethite $(\mathrm{a}-\mathrm{FeOOH})$ particles: an experimental and modeling study, Geochim. Cosmochim. Acta 67 (2003) (5), pp. 967-983.

Gilbert et al., 1991 P. Gilbert, D.J. Evans, E. Evans, I.G. Duguid and M.R.W. Brown, Surface characteristics and adhesion of Escherichia coli and Staphylococcus epidermis, J. Appl. Bacteriol. 71 (1991), pp. 72-77.

Gimbel and Sontheimer, 1980 R.D. Gimbel and H. Sontheimer, Einfluss der Oberflächenstruktur von Filtermaterialien auf die Partikelabscheidung in Tieffiltern, Vom Wasser 55 (1980), pp. 131-147.

Goldshmid et al., 1973 J. Goldshmid, D. Zohar, Y. Argamon and Y. Kott, Effects of dissolved salts on the filtration of coliform bacteria in sand dunes. In: S.H. Jenkins, Editor, Advances in Water Pollution Research, Pergamon Press, New York (1973), pp. 147-155.

Gonzalez et al., 1992 J.M. Gonzalez, J. Iribirri, L. Egea and I. Barcina, Characterization of culturability, protistan grazing, and death of enteric bacteria in aquatic ecosystems, Appl. Environ. Microbiol. 58 (1992), pp. 998-1004.

Hagedorn et al., 1978 C. Hagedorn, D.T. Hansen and G.H. Simonson, Survival and movement of fecal indicator bacteria in soil under conditions of saturated flow, J, Environ. Qual. 7 (1978), pp. 55-59.

Hagedorn et al., 1981 C. Hagedorn, E.L. McCoy and T.M. Rahe, The potential for ground water contamination from septic effluents, J. Environ. Qual. 10 (1981) (10), pp. 1-8.

Hahn and O'Melia, 2004 M.W. Hahn and C.R. O'Melia, Deposition and reentrainment of Brownian particles in porous media under unfavorable chemical conditions: some concepts and applications, Environ. Sci. Technol. 38 (2004), pp. 210-220.

Hall, 1957 Hall, W.A., 1957. An analysis of sand filtration. J. Sanitary Engineering Division. Proc. Am. Soc. Civ. Eng. 83 (SA 3), 1276/1-1276/9.

Harvey, 1997 R.W. Harvey, Microorganisms as tracers in groundwater injection and recovery experiments: a review, FEMS Microbiol. Rev. 20 (1997), pp. 461-472.

Harvey and Garabedian, 1991 R.W. Harvey and S.P. Garabedian, Use of colloid filtration theory in modeling movement of bacteria through a contaminated sandy aquifer, Environ. Sci. Technol. 25 (1991), pp. 178-185.

Havemeister and Riemer, 1985 G. Havemeister and R. Riemer, Laborversuche zum Transportverhalten von Bakterien, Umweltbundesambt Materialien 2/85 (1985), pp. 27-32.

Hijnen et al., 2004 W.A.M. Hijnen, J.F. Schijven, P. Bonne, A. Visser and G.J. Medema, Elimination of viruses, bacteria and protozoan oocysts by slow sand filtration, Wat. Sci. Technol. 50 (2004) (1), pp. $147-154$.

Hendry et al., 1997 M.J. Hendry, J.R. Lawrence and P. Maloszewski, The role of sorption in the transport of Klebsiella oxytoca through saturated silica sand, Ground Water 35 (1997) (4), pp. 574584.

Hendry et al., 1999 M.J. Hendry, J.R. Lawrence and P. Maloszewski, Effects of velocity on the transport of two bacteria through saturated sand, Ground Water 37 (1999) (1), pp. 103-112.

Herzig et al., 1970 Herzig, J.P., Leclerc, D.M., Le Golf, P., 1970. Flow of suspensions through porous media-Application to deep infiltration. In: Flow Through Porous Media, Am. Chem. Soc., Washington, DC, pp. 129-157.

Hull, 1997 S. Hull, Escherichia coli lipopolysaccharide in pathogenesis and virulence. In: M. Sussman, Editor, Escherichia coli: mechanisms of virulence, Cambridge University Press, Cambridge, UK (1997), pp. 145-167. 
Iriberri et al., 1994 J. Iriberri, I. Azua, A. Labirua-Iturburu, I. Artolozaga and I. Barcina, Differential elimination of enteric bacteria by protists in a freshwater system, J. Appl. Microbiol. 77 (1994), pp. 476-483.

Iwasaki, 1937 T. Iwasaki, Some notes on sand filtration, J. Am. Water Works Ass. 29 (1937) (10), pp. 1591-1602.

James, 1957 A.M. James, The electrochemistry of the bacterial surface, Progr. Biophys. Biophys. Chem. 8 (1957), pp. 95-142.

Johnson and Elimelech, 1995 P.R. Johnson and M. Elimelech, Dynamics of colloid deposition in porous media: blocking based on random sequential adsorption, Langmuir 11 (1995), pp. 802-812.

Johnson et al., 1996 P.R. Johnson, N. Sun and M. Elimelech, Colloid transport in geochemically heterogeneous porous media: modelling and measurements, Environ. Sci. Technol. 30 (1996), pp. 3284-3293.

Johnson et al., 1995 W.P. Johnson, K.A. Blue, B.E. Logan and R.G. Arnold, Modeling bacterial detachment during transport through porous media as a residence-time-dependent process, Water Resour. Res. 31 (1995) (11), pp. 2649-2658.

Kaper et al., 2004 J.B. Kaper, J.P. Nataro and H.L.T. Mobley, Pathogenic Escherichia coli, Nature Rev. Microbiol. 2 (2004), pp. 123-140.

Karim et al., 2004a Karim, M.R., LeChevallier, M. W., Abbaszadegan, M., Alumm A., Sobrinho, J., Rosen, J., 2004a. Field testing of USEPA Methods 1601 and 1602 for coliphage in groundwater. AWWA Research Foundation. ISBN 1-58321-348-1.

Karim et al., 2004b M.R. Karim, F.D. Manshadi, M.M. Karpiscak and C.P. Gerba, The persistence and removal of enteric pathogens in constructed wetlands, Water Res. 38 (2004), pp. 1831-1837.

Kastowksy et al., 1991 M. Kastowksy, A. Sabisch, T. Gutberlet and H. Bradaczek, Molecular modelling of bacterial deep rough mutant lipopolysaccharide of Escherichia coli, Eur. J. Biochem. 197 (1991), pp. 707-716.

Kerr et al., 1999 M. Kerr, M. Fitzgerald, J.J. Sheridan, D.A. McDowell and I.S. Blair, Survival of Escherichia coli O157:H7 in bottled natural mineral water, J. Appl. Microbiol. 87 (1999), pp. 833-841.

Keswick et al., 1982 B.H. Keswick, C.P. Gerba, S.L. Secor and I. Cech, Survival of enteric viruses and indicator bacteria in groundwater, J. Environ. Sci. Health A 17 (1982) (6), pp. 903-912.

Kim and Corapcioglu, 1996 S. Kim and M.Y. Corapcioglu, A kinetic approach to modeling mobile bacteria-facilitated groundwater contaminant transport, Water Resour. Res. 32 (1996) (2), pp. 321 331.

Kjelleberg and Hermansson, 1984 S. Kjelleberg and M. Hermansson, Starvation-induced effects on bacterial surface characteristics, Appl. Environ. Microbiol. 48 (1984), pp. 497-503.

Ko et al., 2000 C.H. Ko, S. Bhattacharjee and M. Elimelech, Coupled influence of colloidal and hydrodynamic interactions on the RSA blocking function for particle deposition onto packed spherical collectors, J. Colloid Interface Sci. 229 (2000), pp. 554-567.

Korhonen and Martikainen, 1991 L.K. Korhonen and P.J. Martikainen, Survival of Escherichia coli and Campylobacter jejuni in untreated and filtered lake water, J. Appl. Bacteriol. 71 (1991), pp. 379-382.

Kudryavtseva, 1972 B.M. Kudryavtseva, An experimental approach to the establishment of zones of hygienic protection of underground water sources on the basis of sanitary-bacteriological indices, $J$. Hyg. Epidemiol. Microbiol. Immun. 16 (1972), pp. 503-511.

Lewis et al., 1980 Lewis, W.J., Foster, S.S.D., Drasar, B.S., 1980. The risk of groundwater pollution by on-site sanitation in developing countries. IRCWD Report No. 01/82. International Reference Centre for Waste Disposal (IRCWD), Duebendorf, Switzerland. 
Li et al., 2004 X. Li, T.D. Scheibe and W.P. Johnson, Apparent decreases in colloid deposition rate coefficients with distance of transport under unfavorable deposition conditions: a general phenomenon, Environ. Sci. Technol. 38 (2004), pp. 5616-5625.

Lindqvist and Bengtsson, 1991 R. Lindqvist and G. Bengtsson, Dispersal dynamics of groundwater bacteria, Microb. Ecol. 21 (1991), pp. 49-72.

Lindqvist et al., 1994 R. Lindqvist, J.S. Cho and C.G. Enfield, A kinetic model for cell density dependent bacterial transport in porous media, Water Res. Res. 30 (1994) (12), pp. 3291-3299.

Liu et al., 1995 D. Liu, P.R. Johnson and M. Elimelech, Colloid deposition dynamics in flow through porous media: role of electrolyte concentration, Environ. Sci. Technol. 29 (1995), pp. 2963-2973.

Logan et al., 1995 B.E. Logan, D.G. Jewett, R.G. Arnold, E.J. Bouwer and C.R. O'Melia, Clarification of clean-bed filtration models, J. Environ. Eng. Dec. 1995 (1995), pp. 869-873.

Macler and Merkle, 2000 B.A. Macler and J.C. Merkle, Current knowledge on groundwater microbial pathogens and their control, Hydrogeol. J. 8 (2000) (1), pp. 29-40.

Martin et al., 1992 R.E. Martin, E.J. Bouwer and L.M. Hanna, Application of clean-bed filtration theory to bacteria deposition in porous media, Environ. Sci. Technol. 26 (1992) (5), pp. 1053-1058.

Matthess, 1982 G. Matthess, The Properties of Groundwater, Wiley, New York (1982) ISBN0-47108513-8.

Matthess and Pekdeger, 1981 Matthess, G., Pekdeger, A., 1981. Concepts of a survival and transport model of pathogenic bacteria and viruses in groundwater. In: Van Duijvenbooden, W., Glasbergen, P., van Lelyveld, H. (Eds.), Quality of Groundwater, Proceedings of an International Symposium, pp. 427437.

Matthess and Pekdeger, 1985 G. Matthess and A. Pekdeger, Survival and transport of pathogenic bacteria and viruses in groundwater. In: C.H. Ward, W. Giger and P.L. McCarty, Editors, Groundwater Quality, Wiley, New York (1985), pp. 472-482.

Matthess et al., 1985 G. Matthess, S.S.D. Foster and A.C. Skinner, Theoretical background, hydrogeology and practice of groundwater protection zones, IAH Int. Contribut. Hydrogeol. 6 (1985), p. 1985.

Matthess et al., 1988 G. Matthess, A. Pekdeger and J. Schroeter, Persistence and transport of bacteria and viruses in groundwater-a conceptual evaluation, J. Cont. Hydrol. 77 (1988) (2), pp. 171-188.

Matthess et al., 1991a Matthess, G., Bedbur, E., Gundermann, K.O., Loof, M., Peters, D., 1991a. Vergleichende Untersuchung zum Filtrationsverhalten von Bakterien und organischen Pertikeln in Porengrundwasserleitern I. Grundlagen und Methoden. Zentrallblatt für Hygiene und Umweltmedizin 191, Gustav Fischer Verlag Stuttgart/New York, pp. 53-97.

Matthess et al., 1991b Matthess, G., Bedbur, E., Gundermann, K.O., Loof, M., Peters, D., 1991b. Vergleichende Untersuchung zum Filtrationsverhalten von Bakterien und organischen Pertikeln in Porengrundwasserleitern II. Hydraulische, hydrochemische unde sedimentologische Systemeigenschaften, die den Filterfaktor steuern. Zentrallblatt für Hygiene und Umweltmedizin 191, Gustav Fischer Verlag Stuttgart/New York, pp. 347-395.

McCaulou et al., 1995 D. McCaulou, R.C. Bales and R.G. Arnold, Effect of temperature-controlled motility on transport of bacteria and microspheres through saturated sediment, Water Res. Res. 31 (1995) (2), pp. 271-280.

McCoy and Hagedorn, 1979 E.L. McCoy and C. Hagedorn, Quantitatively tracing bacterial transport in saturated soil systems, Water Air Soil Pollut. 11 (1979), pp. 467-479.

McCoy and Hagedorn, 1980 E.L. McCoy and C. Hagedorn, Transport of resistance-labeled Escherichia coli strains through a transition between two soils in a topographic sequence, J. Environ. Qual. 9 (1980), pp. 686-691. 
McFeters and Stuart, 1972 G.A. McFeters and D.G. Stuart, Survival of coliform bacteria in natural waters: field and laboratory studies with membrane-filter chambers, Appl. Microbiol. 24 (1972) (5), pp. 805-811.

McFeters et al., 1974 G.A. McFeters, G.K. Bissonnettee, J.J. Jezeski, C.A. Thomson and D.G. Stuart, Comparative survival of indicator bacteria and enteric pathogens in well water, Appl. Microbiol. 270 (1974), pp. 823-829.

Medema et al., 2003 Medema, G.J., Payment, P., Dufour, A., Robertson, W., Waite, M., Hunter, P., Kirby, R., Andersson, Y., 2003. Safe drinking water: an ongoing challenge. In: Dufour et al. (Eds.), Assessing Microbial Safety of Drinking Water: Improving Approaches and Methods, World Health Organization, 2003. ISBN 924154630.

Merkli, 1975 Merkli, B., 1975. Untersuchungen ueber Mechanismen und Kinetik der Elimination von Bakterien und Viren im Grundwasser. Diss. ETH Zurich 5420.

Moreira et al., 1994 L. Moreira, P. Agostinho, P. Vasconcellos Morais and M.S. da Costa, Survival of allochthonous bacteria in still mineral water bottled in polyvinyl chloride (PVC) and glass, J. Appl. Bacteriol. 77 (1994), pp. 334-339.

Murphy and Ginn, 2000 E.M. Murphy and T.R. Ginn, Modelling microbial processes in porous media, Hydrogeol. J. 8 (2000) (1), pp. 142-158.

Nasser et al., 1993 A.M. Nasser, Y. Tchorch and B. Fattal, Comparative survival of Escherichia coli F+bacteriophages, HAV and poliovirus in wastewater and groundwater, Water Sci. Tech. 27 (1993), pp. 401-407.

Neihof, 1969 R. Neihof, Microelectrophoresis apparatus employing palladium electrodes, J. Coll. Interface Sci. 30 (1969) (1), pp. 128-133.

Neumann, 1983 Neumann, B., 1983. Untersuchungen zur Elekrophorese als Transportmechanismus bei der Tiefinfiltration. Diss. Universität Fridericana Karlsruhe, Fakultät für Chemieingenieurwesen.

Noda and Kanemasa, 1986 Y. Noda and Y. Kanemasa, Determination of hydrophobicity on bacterial surfaces by nonionic surfactants, J. Bact. 167 (1986) (3), pp. 1016-1019.

Pang et al., 2003 L. Pang, M. Close, M. Goltz, L. Sinton, H. Davies, C. Hall and G. Stanton, Estimation of septic tank setback distances based on transport of Escherichia coli and F-RNA phages, Environ. Int 29 (2003), pp. 907-921.

Payment et al., 2003 Payment, P., Waite, M., Dufour, A., 2003. Introducing parameters for the assessment of drinking water quality. In: Dufour et al. (Eds.), Assessing Microbial Safety of Drinking Water: Improving Approaches and Methods, World Health Organization, ISBN 924154630.

Peters, 1989 Peters, D., 1989. Der Einfluss hydraulischer und sedimentologischer Eigenschaften gleich förmiger Sande auf die Filtration ausgewählter Bakterienarten. Berichte-Reports, Geol. Pal. Inst. Univ. Kiel 29, pp. 1-109.

Powelson and Mills, 2001 D.K. Powelson and A.L. Mills, Transport of Escherichia coli in sand columns with constant and changing water contents, J. Environ. Qual. 30 (2001), pp. 238-245.

Rajagopalan and Tien, 1976 R. Rajagopalan and C. Tien, Trajectory analysis of deep-bed filtration with the sphere-in-a-cell porous media model, AIChE J. 22 (1976) (3), pp. 523-533.

Rahe et al., 1978 T.M. Rahe, C. Hagedorn, E.L. McCoy and G.F. Kling, Transport of antibiotic-resistant Escherichia coli through western Oregon hillslope soils under conditions of saturated flow, J. Envrion. Qual. 7 (1978), pp. 487-494.

Ramalho et al., 2001 R. Ramalho, A. Afonso, J. Cunha, P. Teizeira and P.A. Gibbs, Survival characteristics of pathogens inoculated into bottled mineral water, Food Control 12 (2001), pp. 311316. 
Reddy et al., 1981 K.R. Reddy, R. Khaleel and M.R. Overcash, Behavior and transport of microbial pathogens and indicator organisms in soils treated with organic wastes, J. Environ. Qual. 10 (1981), pp. 255-266.

Redman et al., 2001 J.A. Redman, S.B. Grant, T.M. Olson and M.K. Estes, Pathogen filtration, heterogeneity, and the potable resue of wastewater, Environ. Sci. Technol. 35 (2001), pp. 17981805.

Redman et al., 2004 J.A. Redman, S.L. Walker and M. Elimelech, Bacterial adhesion and transport in porous media: role of the secondary energy minimum, Environ. Sci. Technol. 38 (2004), pp. 17771785.

Reneau, 1978 R.B. Reneau, Influence of artificial drainage on penetration of coliform bacteria from septic tank effluents into wet tile drained soils, J. Environ. Qual. 7 (1978), pp. 23-30.

Reneau and Pettry, 1975 R.B. Reneau and D.E. Pettry, Movement of coliform bacteria from septic tank effluent through selected coastal plain soils of Virginia, J. Environ. Qual. 4 (1975), pp. 41-44.

Rice et al., 1992 E.W. Rice, C.H. Johnson, D.K. Wild and D.J. Reasoner, Survival of Escherichia coli O157:H7 in drinking water associated with a waterborne disease outbreak of hemorrhagic colitis, Ltt. Appl. Microbiol. 15 (1992), pp. 38-40.

Rijnaarts et al., 1996 H.M. Rijnaarts, W. Norde, E.J. Bouwer, J. Lykklema and A.J.B. Zehnder, Bacterial deposition in porous media related to the clean bed collision efficiency and to substratum blocking by attached cells, Environ. Sci. Technol. 30 (1996) (10), pp. 2869-2876.

Romero, 1970 J.C. Romero, The movement of bacteria and viruses through porous media, Ground Water 8 (1970), pp. 37-48.

Ryan and Elimelech, 1996 J. Ryan and M. Elimelech, Review: Colloid mobilization and transport in groundwater, Colloids Surf A: Physicochem. Eng. Aspects 107 (1996), pp. 1-56.

Ryan et al., 1999 J.N. Ryan, M. Elimelech, R.A. Ard, R.W. Harvey and P.R. Johnson, Bacteriophage PRD1 and silica colloid transport and recovery in an iron oxide-coated sand aquifer, Environ. Sci. Technol. 33 (1999), pp. 63-73.

Sawyer et al., 1994 C.N. Sawyer, P.L. McCarthy and G.F. Parkin, Chemistry for Environmental Engineering (4th ed), McGraw-Hill, New York (1994) ISBN 0-07-113908-7.

Schaub and Sorber, 1977 S.A. Schaub and C.A. Sorber, Virus and bacteria removal from wastewater by rapid infiltration through the soil, Appl. Environ. Microbiol. 33 (1977), pp. 609-619.

Scholl et al., 1990 M.A. Scholl, A.L. Mills, J.S. Herman and G.M. Hornberger, The influence of mineralogy and solution chemistry on the attachment of bacteria to representative aquifer minerals, $\mathrm{J}$. Contam. Hydrol. 6 (1990), pp. 321-336.

Scholl and Harvey, 1992 M.A. Scholl and R.W. Harvey, Laboratory investigations on the role of sediment surface and groundwater chemistry in transport of bacteria through a contaminated sandy aquifer, Environ. Sci. Technol. 26 (1992) (7), pp. 1410-1417.

Schijven, 2001 Schijven, J.F., 2001. Virus removal from groundwater by soil passage. Modelling field and laboratory experiments. Ph.D. Thesis. ISBN 90-646-4046-7. Ponsen and Looijen, Wageningen, The Netherlands.

Sharma et al., 1985 M.M. Sharma, Y.I. Chang and T.F. Yen, Reversible and irreversible surface charge modification of bacteria for facilitating transport through porous media, Colloids Surf. 16 (1985), pp. 193-206.

Simoni et al., 1998 S.F. Simoni, H. Harms, T.N.P. Bosma and A.J.B. Zehnder, Population heterogeneity affects transport of bacteria through sand columns at low flow rates, Environ. Sci. Technol. 32 (1998), pp. 2100-2105. 
Šimůnek et al., 2003 J. Šimůnek, N.J. Jarvis, M.T. van Genuchten and A. Gärdenäs, Review and comparison of models for describing non-equilibrium and preferential flow and transport in the vadose zone, J. Hydrol. 272 (2003), pp. 14-35

Sinton, 2001 L.W. Sinton, Microbial contamination of New Zealand's aquifers. In: M.R. Rosen and P.A. White, Editors, Groundwaters of New Zealand, New Zealand Hydrological Society Inc, Wellington (2001), pp. 221-251.

Sinton et al., 1997 L.W. Sinton, R.K. Finlay, L. Pang and D.M. Scott, Transport of bacteria and bacteriophages in irrigated effluent into and through an alluvial gravel aquifer, Water Air Soil Pollut. 98 (1997), pp. 17-42.

Sinton et al., 2000 L.W. Sinton, M.J. Noonan, R.K. Finaly, L. Pang and M.E. Close, Transport and attenuation of bacteria and bacteriophages in an alluvial gravel aquifer, NZ J. Marine Freshwater Res. 34 (2000), pp. 175-186.

Sjogren, 1994 R.E. Sjogren, Prolonged survival of an environmental Escherichia coli in laboratory soil microcosms, Water Air Soil Pollut. 75 (1994), pp. 389-403.

Smith et al., 1985 M.S. Smith, G.W. Thomas, R.E. White and D. Ritonga, Transport of Escherichia coli through intact and disturbed soil columns, J. Environ. Qual. 14 (1985), pp. 87-91.

Somasundaran and Agar, 1967 P. Somasundaran and G.E. Agar, The zero point of charge of calcite, J. Coll. Interface Sci. 24 (1967), pp. 433-440.

Stevik et al., 1999 T.K. Stevik, G. Ausland, J.F. Hanssen and P.D. Jenssen, The influence of physical and chemical factors on the transport of Escherichia coli through biological filters for wastewater purification, Water Res. 33 (1999), pp. 3701-3706.

Stevik et al., 2004 T.K. Stevik, K. Aa, G. Ausland and J.F. Hanssen, Retention and removal of pathogenic bacteria in wastewater percolating through porous media: a review, Water Res. 38 (2004), pp. $1355-1367$

Stumm and Morgan, 1996 W. Stumm and J.J. Morgan, Aquatic Chemistry (3rd ed), Wiley, New York (1996).

Sun et al., 2001 N. Sun, M. Elimelech, N.-Z. Sun and J.N. Ryan, A novel two-dimensional model for colloid transport in physically and geochemically heterogeneous porous media, J. Contam. Hydrol. 49 (2001), pp. 173-199.

Tan et al., 1994 Y. Tan, J.T. Gannon, P. Baveye and M. Alexander, Transport of bacteria in an aquifer sand: experiments and model simulations, Water Res. 30 (1994) (12), pp. 3243-3252.

Tate, 1978 R.L. Tate, Cultural and environmental factors affecting the longevity of Escherichia coli in histosoils, Appl. Environ. Microbiol. 35 (1978), pp. 925-929.

Tobiason and O'Melia, 1988 J.E. Tobiason and C.R. O'Melia, Physicochemical aspects of particle removal in depth infiltration, J. AWWA 80 (1988), pp. 54-64. Abstract + References in Scopus | Cited By in Scopus

Toride et al., 1999 Toride, N., Leij, F.J., van Genuchten, M.T., 1999. The CXTFIT code for estimating transport parameters from laboratory or field tracer experiments, version 2.1. Research Report No.137, US Salinity Laboratory, US Department of Agriculture, Riverside, CA. Internet site: http://www.ussl.ars.usda.gov/models/modelsmenu.htm.

Tufenkji et al., 2003 N. Tufenkji, J.A. Redman and M. Elimelech, Interpreting deposition patterns of microbial particles in laboratory-scale column experiments, Environ. Sci. Technol. 37 (2003), pp. 616623.

Tufenkji and Elimelech, 2004a N. Tufenkji and M. Elimelech, Correlation equation for predicting singlecollector efficiency in physicochemical filtration in saturated porous media, Environ. Sci. Technol $\mathbf{3 8}$ (2004), pp. 529-536. 
Tufenkji and Elimelech, 2004b N. Tufenkji and M. Elimelech, Deviation from classical colloid filtration theory in the presence of repulsive DLVO interactions, Langmuir 20 (2004), pp. 10818-10828.

Tufenkji and Elimelech, 2005a N. Tufenkji and M. Elimelech, Spatial distributions of Cryptosporidium oocysts in porous media: evidence for dual mode deposition, Environ. Sci. Technol. 39 (2005), pp. 3620-3629.

Tufenkji and Elimelech, 2005b N. Tufenkji and M. Elimelech, Breakdown of colloid filtration theory: role of the secondary energy minimum and surface charge heterogeneities, Langmuir 21 (2005), pp. 841-852.

Tufenkji et al., 2004 N. Tufenkji, G.F. Miller, J.N. Ryan, R.W. Harvey and M. Elimelech, Transport of Cryptosporidium oocysts in porous media: role of straining and physicochemical filtration, Environ. Sci. Technol. 38 (2004), pp. 5932-5938.

van Donsel et al., 1967 D.J. van Donsel, E.E. Geldreich and N.A. Clarke, Seasonal variations in survival of indicator bacteria in soil and their contribution to storm-water pollution, Appl. Microbiol. 15 (1967), pp. 1362-1370.

van Loosdrecht et al., 1987a M.C.M. van Loosdrecht, J. Lyklema, W. Norde, G. Schraa and A.J.B. Zehnder, The role of bacterial cell wall hydrophobicity in adhesion, App. Environ. Microbiol. 1987 (1987), pp. 1893-1897.

van Loosdrecht et al., 1987b M.C.M. van Loosdrecht, J. Lyklema, W. Norde, G. Schraa and A.J.B. Zehnder, Electrophoretic mobility and hydrophobicity as a measure to predict the initial steps of bacterial adhesion, App. Environ. Microbiol. 1987 (1987), pp. 1898-1901.

Viraraghavan, 1978 T. Viraraghavan, Travel of microorganisms from a septic tile, Water Air Soil Pollut. 9 (1978), pp. 355-362.

Walker et al., 2004 S.L. Walker, J.A. Redman and M. Elimelech, Role of cell surface lipopolysaccharides in Escherichia coli K12 adhesion and transport, Langmuir 20 (2004), pp. 77367746.

Walker et al., 2005 S.L. Walker, J.A. Redman and M. Elimelech, Influence of growth phase on bacterial deposition: interaction mechanisms in packed-bed column and radial stagnation point flow systems", Environ, Sci. Technol. 39 (2005), pp. 6405-6411.

Wang and Doyle, 1998 G. Wang and M.P. Doyle, Survival of enterohemorrhagic Escherichia coli O157:H7 in water, J. Food Protec. 61 (1998), pp. 662-667.

Webtech360, 2003 Webtech360, 2003. Processing Modflow Pro, http://www.iesinet.com.

World Health Organization, 2000-2003 World Health Organization, 2000-2003. Global Water Supply and Sanitation Assessment 2000 Report.

http://www.who.int/docstore/water_sanitation_health/globassessment.

Yao et al., 1971 K.-M. Yao, M.T. Habibian and C.R. O'Melia, Water and wastewater filtration: Concepts and applications, Environ. Sci. Technol. 5 (1971) (11), pp. 1105-1112.

Zeng and Wang, 1999 Zeng, C., Wang, P.P., 1999. MT3DMS: A modular three-dimensional multispecies transport model for simulation of advection, dispersion, and chemical reactions of contaminants in groundwater systems; documentation and user's guide. US Army Corps of Engineers Engineer Research and Development Center Contract Report SERDP-99-1.

Ziebell et al., 1975 Ziebell, W.A., Nero, D.H., Deininger, J.F., McCoy, E., 1975. Use of bacteria in assessing waste treatment and soil disposal systems. In: Home Sewage Disposal, Proceedings of the National Home Sewage Disposal Symposium of the American Society of Agricultural Engineers, pp. 58-63. 